\title{
Differences in Amino Acid Composition between $\alpha$ and $\beta$ Structural Classes of Proteins
}

\author{
Hiroshi Nakashima*, Yuka Saitou, Nachi Usuki \\ Department of Clinical Laboratory Science, Graduate Course of Medical Science and Technology, \\ School of Health Sciences, Kanazawa University, Kanazawa, Japan \\ Email: ${ }^{\text {naka@kenroku.kanazawa-u.ac.jp }}$
}

Received 6 July 2014; revised 21 August 2014; accepted 7 September 2014

Copyright (C) 2014 by authors and Scientific Research Publishing Inc.

This work is licensed under the Creative Commons Attribution International License (CC BY). http://creativecommons.org/licenses/by/4.0/

c) (i) Open Access

\section{Abstract}

The amino acid composition of $\alpha$ and $\beta$ structural class of proteins from five species, Escherichia coli, Thermotoga maritima, Thermus thermophilus, yeast, and humans were investigated. Amino acid residues of proteins were classified into interior or surface residues based on the relative accessible surface area. The hydrophobic Leu, Ala, Val, and Ile residues were rich in interior residues, and hydrophilic Glu, Lys, Asp, and Arg were rich in surface residues both in $\alpha$ and $\beta$ proteins. The amino acid composition of $\alpha$ proteins was different from that of $\beta$ proteins in five species, and the difference was derived from the different contents of their interior residues between $\alpha$ and $\beta$ proteins. $\alpha$-helix content of $\alpha$ proteins was rich in interior residues than surface ones. Similarly, $\beta$ sheet content of $\beta$ proteins was rich in interior residues than surface ones. The content of Leu residues was very high, approximately $20 \%$, in interior residues of $\alpha$ proteins. This result suggested that the Leu residue plays an important role in the folding of $\alpha$ proteins.

\section{Keywords}

Amino Acid Composition, $\alpha$ and $\beta$ Proteins, Interior/Surface Residue, Protein Domains, Species-Specific Amino Acid Composition

\section{Introduction}

Nearly 30 years ago, Nakashima et al. [1] reported that the amino acid composition of proteins is different among the four structural classes: $\alpha, \beta, \alpha / \beta$ and $\alpha+\beta$. Many studies [2]-[8] have confirmed that there is a corre-

\footnotetext{
*Corresponding author.
}

How to cite this paper: Nakashima, H., Saitou, Y. and Usuki, N. (2014) Differences in Amino Acid Composition between $\alpha$ and $B$ Structural Classes of Proteins. J. Biomedical Science and Engineering, 7, 890-918. 
lation between the amino acid composition and structural class of proteins. However, the reason behind the differences in amino acid composition among different structural classes is not clearly understood.

It is known that bacteria have species-specific nucleotide compositions in their protein-coding genes [9]-[11]. Due to the biased nucleotide composition, the amino acid composition of bacteria is also biased. The accumulation of data of the three-dimensional (3D) structure of proteins has provided the opportunity to statistically analyze the amino acid composition of proteins of different structural classes from different species. Here, we compared the amino acid composition of proteins form five species; Escherichia coli, Thermotoga maritima, Thermus thermophilus, yeast (Saccharomyces cerevisiae), and humans (Homo sapiens), because these species have relatively large numbers of structural proteins. The species-specific nucleotide composition is largely dependent on $\mathrm{G}+\mathrm{C}$ content. The $\mathrm{G}+\mathrm{C}$ content in the whole genome is $50.8 \%$ in E. coli, $46.2 \%$ in T. maritima, $69.5 \%$ in $T$. thermophilus, and $38.3 \%$ in yeast. These four species have a constant $\mathrm{G}+\mathrm{C}$ content in their genomes. By contrast, the human genome has a considerably variable $\mathrm{G}+\mathrm{C}$ content according to their chromosomal locations [12]. The optimal growth temperatures of T. maritima and T. thermophilus are $80^{\circ} \mathrm{C}$ and $85^{\circ} \mathrm{C}$, respectively, as they are hyperthermophiles. It is reported that proteins of thermophiles have a different amino acid composition compared to that of mesophiles [13]-[17].

The amino acid composition of $\alpha$ proteins is mostly distinct from that of $\beta$ proteins among the four structural classes [1]. Therefore, comparison of the amino acid composition of $\alpha$ and $\beta$ proteins appears to be ideal approach to understand the differences in amino acid composition between any two structural classes of proteins. As there is a correlation between amino acid composition and structural classes, we hypothesized that there might be some basic features that facilitate the organization of $\alpha$ or $\beta$ proteins and that such features might be conserved. The purpose of this study was to identify such basic features from various sequences. We compared the amino acid composition of $\alpha$ or $\beta$ proteins from five species, and analyzed their interior or surface residues to identify the common features as well as the differences.

\section{Materials and Methods}

\subsection{Amino Acid Sequences}

The amino acid sequences of known 3D structures were obtained from the structural classification of proteins (SCOP) [18] sequence database 1.75 released on the web site http://scop.mrc-lmb.cam.ac.uk/scop/. Each sequence has a Protein Data Bank (PDB) [19] entry code and a SCOP structural classification code, which represents the structural class, fold, superfamily, and family. The amino acid sequences in SCOP are divided into protein domains and the structural class is depicted for individual sequences. The amino acid sequences that constitute protein domains are not always sequential, as some sequences are composed of two fragments from separate regions. Sequences longer than 100 amino acid residues were selected for this analysis. The sequences of E. coli, T. maritima, T. thermophilus, yeast, and humans were selected, and then the sequences of $\alpha$ or $\beta$ structural class proteins were further selected. The selected sequences were analyzed for their sequence similarity using the BLAST program [20]. The proteins that had more than $25 \%$ sequence identity over 100 residues were excluded to avoid any bias. Sequences with identical SCOP structural codes were included when the sequences had less than $25 \%$ sequence identity over 100 residues. The collected data included 77 sequences of $E$. coli, 22 of T. maritima, 23 of T. thermophilus, 45 of yeast, and 154 of humans for $\alpha$ protein domains, and 90 sequences of E. coli, 17 of T. maritima, 28 of T. thermophilus, 35 of yeast, and 187 of humans for $\beta$ protein domains. The number of total protein domains was 321 for $\alpha$ and 357 for $\beta$ proteins. The protein names, number of residues, and the SCOP and PDB codes of the sequences used in this study are listed in the supplementary data.

\subsection{Classification of Interior/Surface Residues}

The amino acid residues in the analyzed sequences were classified into two types, interior or surface residues, based on their relative solvent accessibility. Solvent accessibility and secondary structure calculated using the DSSP program [21] with the coordinate data of PDB were obtained from the European Bioinformatics Institute web site (http://www.ebi.ac.uk/). Amino acid residues with relative solvent accessibility greater than $25 \%$ were regarded as surface residues, and those with relative solvent accessibility less than $25 \%$ were considered as interior residues as described by Fukuchi and Nishikawa [14]. Secondary structures of a residue were classified into three states: $\alpha$-helix, $\beta$-sheet, and coil. $\alpha$-helices and $\beta$-sheets were categorized according to the definition of the 
DSSP program and residues other than an $\alpha$-helix or $\beta$-sheet were considered as coils. The intrinsically disordered residues were not included in the DSSP sequences. The SCOP amino acid sequences were aligned with DSSP sequences, and the solvent accessibility and secondary structure were given for the corresponding residues between the two sequences.

\subsection{Comparison of Amino Acid Composition}

The average amino acid composition was compared between $\alpha$ and $\beta$ proteins, and interior and surface residues, among the five species. To analyze the amino acid composition of a protein, amino acid composition space, introduced by Nishikawa and Ooi [22]-[24], was employed. The number of each of the 20 types of amino acid residues in a protein sequence was counted and the composition was expressed in a normalized scale using the equation:

$$
V_{i, k}=\left(C_{i, k}-A V_{k}\right) / S D_{k}
$$

where $V_{i, k}$ and $C_{i, k}$ are the normalized and real composition of amino acid residues of the $k$-th component in a sequence $i$, respectively. $A V_{k}$ and $S D_{k}$ are the average composition and the standard deviation of the $k$-th component for the whole dataset, respectively.

The amino acid sequence of a protein was converted to an amino acid composition vector of 20 components and it was plotted as a point in a 20-dimensional composition space. The distribution of proteins was visualized by projecting them onto a two-dimensional (2D) plane, which was defined by two axes of the principal component analysis. A principal component analysis was conducted for the total proteins. The $\mathrm{x}$-coordinate for a given sequence was calculated using the scalar product of the unit vector of the first principal component and the vector of the sequence. The y-coordinate was calculated using the scalar product of the unit vector of the second principal component and the vector of the sequence. The origin of the $x-y$ coordinate system in the composition space was set at the average amino acid composition of all analyzed sequences.

\section{Results}

\subsection{Amino Acid Composition}

The average and standard deviation values of the amino acid composition of total proteins analyzed in this study are indicated in Table 1. The average amino acid compositions of interior, surface, and whole residues of $\alpha$ and $\beta$ structural classes of proteins are listed in Table 1 . The number of domains used in the calculation is shown in the last row in Table 1. The hydrophobic Leu, Ala, Ile, and Val residues were rich in interior residues, and hydrophilic Glu, Lys, Asp, and Arg were rich in surface residues, both in $\alpha$ and $\beta$ proteins. This trend was observed commonly in all five species. The ratios of the interior residues against surface residues clearly indicated that Cys, Phe, Ile, Trp, and Leu were favored as interior residues, and Lys, Glu, Asp, Arg, and Gln were favored as surface residues both in $\alpha$ and $\beta$ proteins. This trend was also observed commonly in all five species. This result indicated that the location of a residue (interior or surface) in a protein is dependent on the character of the amino acid and independent of the structural class. The Leu residues content was very high, approximately $20 \%$, in interior residues of $\alpha$ proteins. To show the difference between $\alpha$ and $\beta$ proteins, the ratios of whole residues of $\alpha$ proteins to those of $\beta$ proteins were calculated. The ratios indicated that Leu, Met, Ala, and Glu residues were predominant in the $\alpha$ proteins of the five species, while Gly, Pro, Val, and Thr residues were predominant in the $\beta$ proteins of the five species. The favored amino acids in the two structural classes of proteins were consistent with a previous study [1].

\subsection{Distribution of $\alpha$ and $\beta$ Proteins on a 2D Plane}

The proteins of $\alpha$ and $\beta$ structural classes of $E$. coli were plotted on a 2D plane by using the first principal component as the $\mathrm{x}$-axis and the second component as the $\mathrm{y}$-axis (Figure 1). The distribution of $\alpha$ proteins of $E$. coli was roughly separated from that of $\beta$ proteins of $E$. coli. A similar plot indicated that $\alpha$ proteins were roughly separated from that of $\beta$ proteins in the other four species, similar to that observed in E. coli. However, the plot of total $\alpha$ and total $\beta$ proteins from the five species together indicated an overlapped distribution.

The variance of the first principal component was $12.6 \%$ and that of the second component was $12.1 \%$. Asn, Ile, Phe, and Ser residues were largely shifted toward the positive direction, while Ala, Arg, Leu, and Glu resi- 
Table 1. Average and standard deviation (SD) of amino acid composition (\%) of total proteins. Average of interior, surface, and whole residues in $\alpha$ and $\beta$ proteins.

\begin{tabular}{|c|c|c|c|c|c|c|c|c|}
\hline \multirow{2}{*}{ Amino acid } & \multicolumn{2}{|c|}{ total proteins } & \multicolumn{3}{|c|}{$\alpha$ proteins } & \multicolumn{3}{|c|}{$\beta$ proteins } \\
\hline & average & $\mathrm{SD}$ & interior & surface & whole & interior & surface & whole \\
\hline Ala & 7.21 & 3.15 & 10.72 & 5.87 & 8.14 & 8.22 & 4.60 & 6.36 \\
\hline Cys & 1.31 & 1.22 & 1.98 & 0.43 & 1.18 & 2.44 & 0.52 & 1.43 \\
\hline Asp & 5.45 & 2.06 & 2.77 & 8.19 & 5.56 & 2.83 & 7.81 & 5.35 \\
\hline Glu & 7.62 & 2.83 & 3.59 & 13.17 & 8.60 & 2.75 & 10.68 & 6.74 \\
\hline Phe & 4.05 & 1.89 & 6.53 & 1.44 & 3.88 & 6.77 & 1.70 & 4.20 \\
\hline Gly & 6.08 & 2.97 & 3.57 & 5.43 & 4.56 & 6.83 & 7.93 & 7.44 \\
\hline His & 2.31 & 1.33 & 1.86 & 2.50 & 2.23 & 2.30 & 2.41 & 2.38 \\
\hline Ile & 5.40 & 2.36 & 9.28 & 2.08 & 5.45 & 8.69 & 2.32 & 5.36 \\
\hline Lys & 6.30 & 2.94 & 1.99 & 11.06 & 6.68 & 1.83 & 9.96 & 5.96 \\
\hline Leu & 10.16 & 3.32 & 19.63 & 4.86 & 11.83 & 13.47 & 4.28 & 8.66 \\
\hline Met & 2.17 & 1.40 & 3.44 & 1.62 & 2.49 & 2.24 & 1.44 & 1.88 \\
\hline Asn & 4.25 & 1.99 & 2.48 & 5.75 & 4.20 & 2.54 & 5.95 & 4.29 \\
\hline Pro & 4.73 & 2.28 & 2.57 & 5.08 & 3.87 & 4.08 & 6.80 & 5.50 \\
\hline Gln & 4.45 & 2.24 & 2.59 & 7.15 & 4.98 & 2.22 & 5.62 & 3.98 \\
\hline Arg & 5.54 & 2.55 & 3.08 & 8.47 & 5.92 & 2.79 & 7.42 & 5.20 \\
\hline Ser & 6.11 & 2.70 & 4.18 & 6.87 & 5.67 & 5.18 & 7.50 & 6.50 \\
\hline Thr & 5.28 & 2.28 & 4.16 & 4.90 & 4.59 & 5.26 & 6.43 & 5.91 \\
\hline Val & 7.03 & 2.64 & 9.12 & 2.73 & 5.78 & 12.70 & 4.04 & 8.16 \\
\hline Trp & 1.33 & 1.06 & 2.02 & 0.48 & 1.22 & 2.30 & 0.58 & 1.44 \\
\hline Tyr & 3.22 & 1.60 & 4.44 & 1.92 & 3.17 & 4.56 & 2.01 & 3.26 \\
\hline Domains & 678 & & & & 321 & & & 357 \\
\hline
\end{tabular}

dues were largely shifted toward the negative direction along the x-axis. Asn, Ile, and Phe residues have A + T-rich codons, and Ala and Arg residues have $\mathrm{G}+\mathrm{C}$-rich codons. This result suggested that the x-axis reflects the character of the $\mathrm{G}+\mathrm{C}$ content of the residues. Along the y-axis, Gly, Pro, Val, and Thr residues showed a larger positive coefficient, and Lys, Glu, Ile, and Met residues showed a larger negative coefficient. The residues with positive coefficients were the favored residues in $\beta$ proteins, and those with negative coefficients were the residues that were mostly detected in $\alpha$ proteins. These findings indicated that the y-axis reflects the frequency of the occurrence of amino acid residues between $\alpha$ and $\beta$ proteins. This is consistent with the distribution of $E$. coli proteins in Figure 1, where most of the $\alpha$ proteins showed negative values of $y$-coordinates, and most of the $\beta$ proteins had positive $\mathrm{y}$-coordinates.

\subsection{Differences in Interior and Surface Compositions among the Five Species}

The average amino acid compositions of interior and surface residues in $\alpha$ proteins from the five species were plotted, and the results are shown in Figure 2 and Figure 3, respectively. To clearly demonstrate the differences in the amino acid content among the five species, the differences between the maximum/minimum and average composition were plotted. Figure 4 shows the plot indicating the differences in the interior composition of $\alpha$ proteins. Ala and Ile residues showed large differences. The Ala residue content in interior composition was highest (16.04\%) in T. thermophilus and lowest (8.51\%) in yeast in $\alpha$ proteins (Figure 2). Since the average Ala 


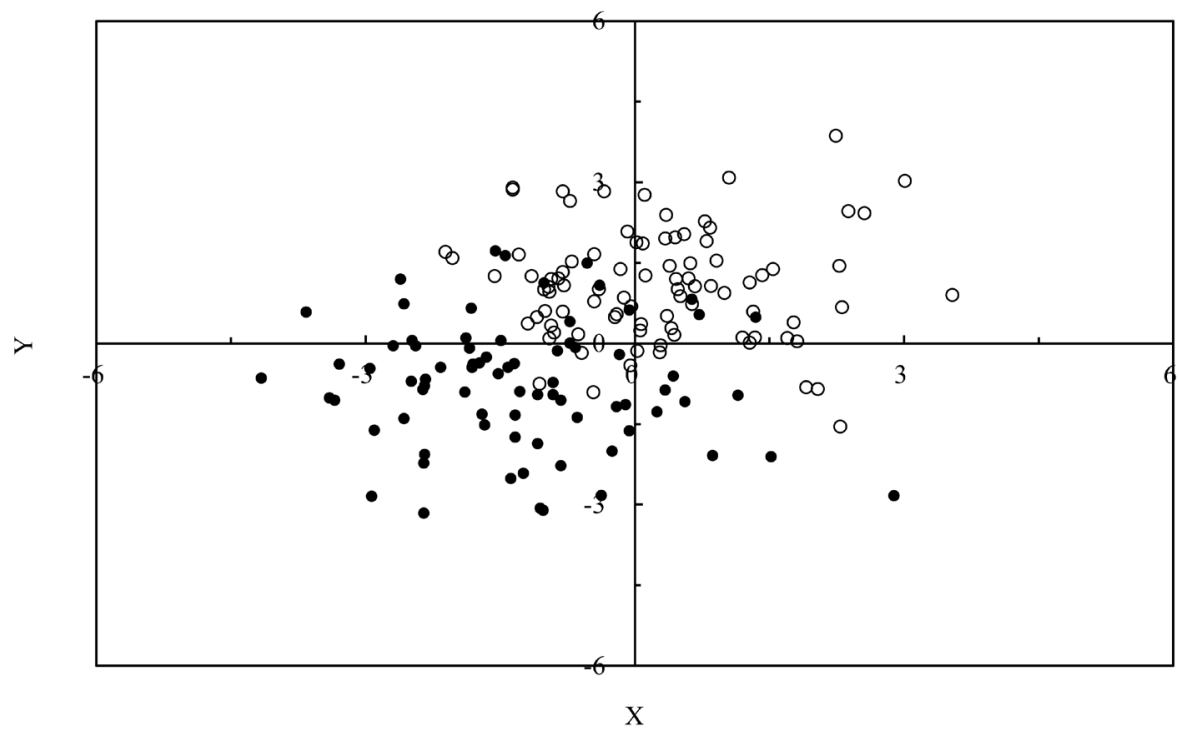

Figure 1. Distribution of $\alpha$ (filled circles) and $\beta$ proteins (open circles) of E. coli. The $\mathrm{x}-$ and $\mathrm{y}$-axes represent the first and second axes determined by principal component analysis.

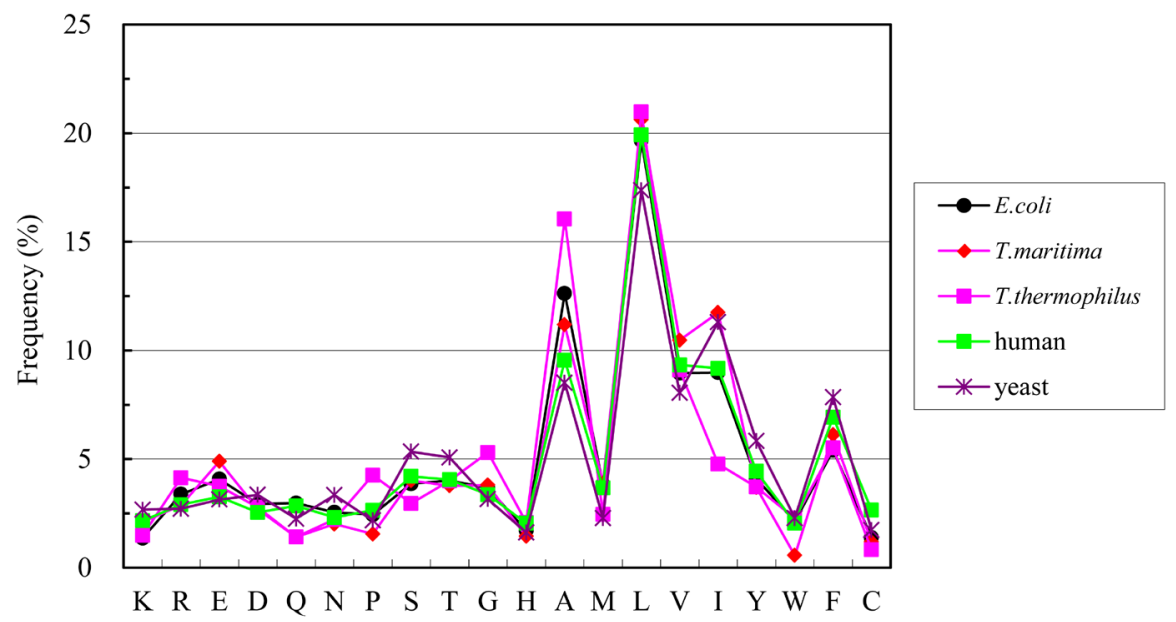

Figure 2. The average amino acid composition of interior residues of $\alpha$ proteins of the five species.

composition in the five species was $11.58 \%$, the deviation was $+4.46 \%$ and $-3.07 \%$ (Figure 4 ). The Ile residue content was lowest (4.77\%) in T. thermophilus and highest (11.30\%) in yeast. Since the average Ile composition in the five species was $9.19 \%$, the deviation was $+2.55 \%$ and $-4.42 \%$ (Figure 4 ). Taken together, the total of Ala and Ile content was $20.81 \%$ in $T$. thermophilus and $19.81 \%$ in yeast. This result indicated that the increase or decrease of Ala content is compensated by the decrease or increase of Ile, and their contents were adjusted in the species with different $\mathrm{G}+\mathrm{C}$ content. The variation in Ala and Ile contents was consistent with previous reports [25]-[29], which indicated that amino acids composed of G + C-rich or A + T-rich codons are related to the genomic $\mathrm{G}+\mathrm{C}$ content of the species.

The differences in the surface composition of $\alpha$ proteins are shown in Figure 5. The Glu residue showed a large difference. The average Glu residue content in the five species was $14.57 \%$. The maximum composition was $19.92 \%$ in T. maritima and the minimum composition was $11.42 \%$ in yeast. Therefore, the difference in the distribution of Glu was $+5.35 \%$ and $-3.15 \%$ (Figure 5). The Glu residue has GAA and GAG codons, which are neutral with respect to $G+C$ content. Therefore, the large differences in the Glu residue content are not explained by the $\mathrm{G}+\mathrm{C}$ content. It has been reported that thermophiles have a higher content of charged residues in 


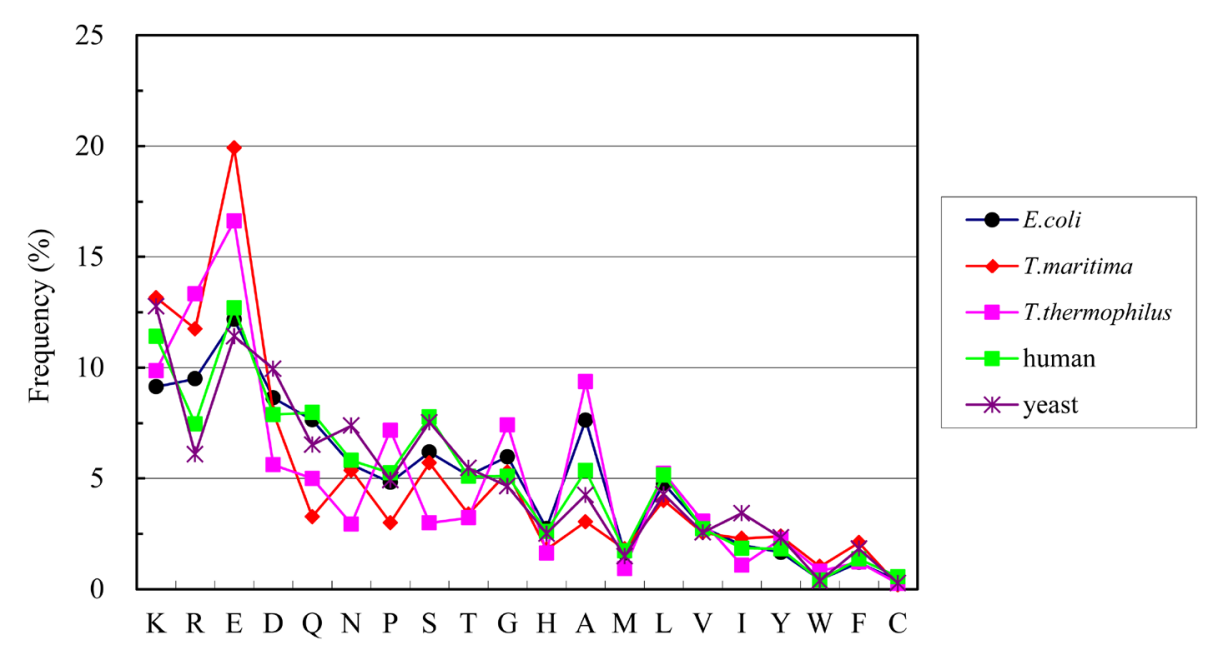

Figure 3. The average amino acid composition of surface residues of $\alpha$ proteins of the five species.

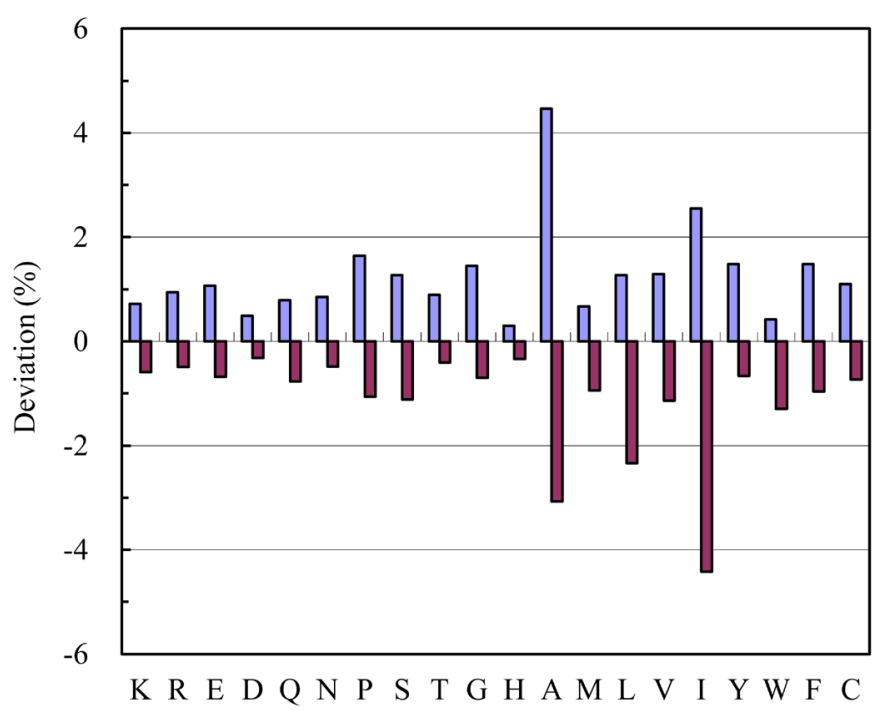

Figure 4. The differences in amino acid content between the maximum and average composition (in blue) and that between the minimum and average composition (in red) of interior residues of $\alpha$ proteins among the five species.

surface composition than mesophiles [14]-[17]. The total content of charged residues of Asp, Glu, Lys, and Arg in the surface composition of $\alpha$ proteins was $52.79 \%$ in T. maritima, $45.42 \%$ in $T$. thermophilus, $39.44 \%$ in E. coli, $39.45 \%$ in humans, and $40.21 \%$ in yeast. The total content of charged residues was higher in thermophiles than in mesophiles, and it was higher in $\alpha$ proteins than in $\beta$ proteins. There were more differences in the composition of surface residues in $\alpha$ proteins than interior residues (Figure 4 and Figure 5). Similar results were observed in $\beta$ proteins. It is empirically known that the interior residues are more conserved than the surface residues in homologous proteins. Therefore, it is reasonable that the interior composition should show less difference than the surface composition.

\section{Discussion}

The amino acid residues were classified into interior or surface residues based on their relative solvent accessibility. The amino acid composition of interior and surface residues was dependent on the classification. In this 


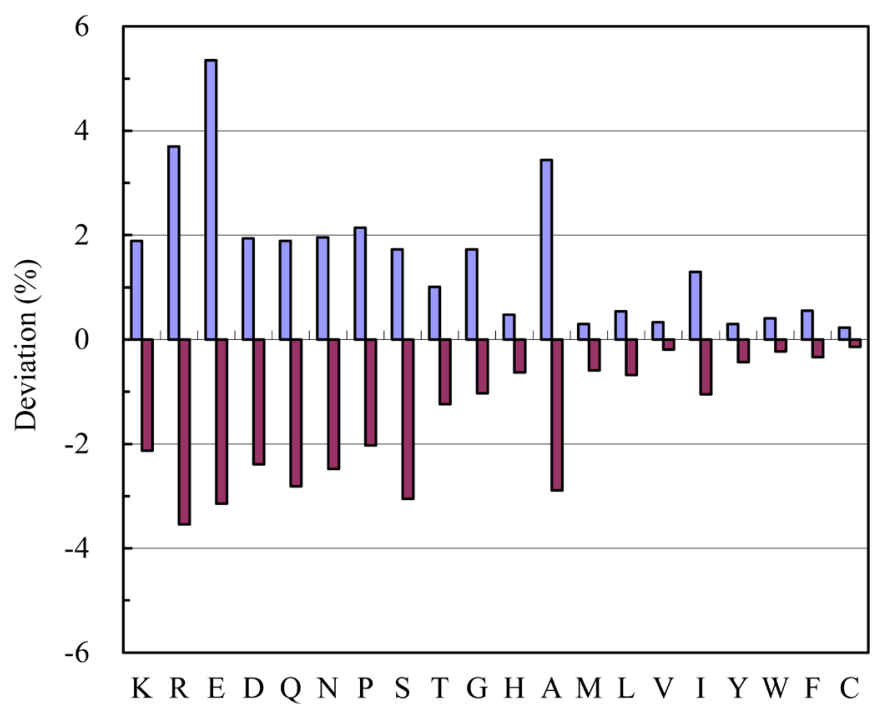

Figure 5. The differences in amino acid content between the maximum and average composition (in blue) and that between the minimum and average composition (in red) of surface residues of $\alpha$ proteins among the five species.

study, an average of surface residues of $\alpha$ proteins of the five species was $51 \%$, and the average of interior residues was $49 \%$. In $\beta$ proteins, the average compositions of both surface and interior residues of the five species were $50 \%$. Since we intended to classify the residues into interior and surface residues in equal proportions, the obtained result met our intended criterion.

The average content of secondary structures in $\alpha$ and $\beta$ proteins is shown in Table 2. The interior residues in $\alpha$ proteins had a higher $\alpha$-helix content, 73\%, than the surface residues. Similarly, the interior residues in $\beta$ proteins had a higher $\beta$-sheet content, $54 \%$, than the surface residues.

The hydrophobic residues, such as Leu, Ala, Ile, and Val were enriched in interior residues of both $\alpha$ and $\beta$ proteins. However, the percentages of $\alpha$-helices and $\beta$-sheets in interior residues were quite different. The reason behind such a big difference is not clear. Since the Ala residue has G + C-rich codons and the Ile residue has A + T-rich codons, their contents were dependent on the $G+C$ content of the species. Therefore, the differences in Ala and Ile compositions were large compared to those of Val and Leu among the five species (Figure 4). The Val residue has GTN (N stands for all four nucleotides) codons, which are neutral with respect to $\mathrm{G}+\mathrm{C}$ content. This might be the reason for the smaller differences observed in Val content. The Leu residue has neutral CTN codons and A + T-rich TTA and TTG codons. The Leu residue showed smaller deviations among species even though its content was consistently high.

In E. coli, the distribution of whole residues of $\alpha$ proteins was roughly distinct from its $\beta$ proteins. Similarly, the interior residues between $\alpha$ and $\beta$ proteins showed a distinct distribution. However, the plot of surface residues in E. coli was overlapped. Similar results were also observed in other species. This indicates that the difference in amino acid composition of whole residues between $\alpha$ and $\beta$ proteins was derived from the differences in the interior residues. This result was obtained by the analysis of the distribution of $\alpha$ and $\beta$ proteins in the amino acid composition space. However, no clear differences were noticed in the initial observations of amino acid composition of interior residues between $\alpha$ and $\beta$ proteins. The interior residues were rich in hydrophobic Leu, Ala, Ile, and Val residues both in $\alpha$ and $\beta$ proteins. To clearly demonstrate the differences in interior residues between $\alpha$ and $\beta$ proteins, the ratios of their amino acid composition were calculated. This indicated that Met, Leu, Glu, and Ala residues were favored in $\alpha$ proteins and Gly, Pro, Val, and Thr were favored in $\beta$ proteins. This trend was observed commonly in all five species. Therefore, we concluded that the existence of favorable residues is a basic common feature of $\alpha$ and $\beta$ proteins. The residues favored in $\alpha$ proteins were consistent with the residues favored in $\alpha$-helix [30], however, Gly and Pro residues favored in $\beta$ proteins were reported as unfavorable in $\beta$-sheet [30]. The Gly and Pro residues contents were not large compared to those of the hydrophobic residues, however, they were commonly favored in $\beta$ proteins in the five species. This suggested that Gly and 
Table 2. Average content of secondary structures (\%).

\begin{tabular}{ccccccc}
\hline & \multicolumn{3}{c}{$\alpha$ proteins } & \multicolumn{3}{c}{$\beta$ proteins } \\
\cline { 2 - 7 } & whole & interior & surface & whole & interior & surface \\
\hline$\alpha$-helix & 63 & 73 & 54 & 9 & 8 & 9 \\
$\beta$-sheet & 2 & 2 & 2 & 39 & 54 & 25 \\
coil & 35 & 25 & 44 & 52 & 38 & 66 \\
\hline
\end{tabular}

Pro residues are essential interior residues in the organization of $\beta$ proteins outside of the $\beta$-sheet regions. The average Leu residue content was $17 \%$ in yeast, and was $20 \%$ in the other four species. This outcome suggested that the interaction between Leu residues is likely to be very large in the interior region and that it might play an important role in the folding of $\alpha$ proteins.

\section{References}

[1] Nakashima, H., Nishikawa, K. and Ooi, T. (1986) Folding Type of a Protein Is Relevant to the Amino Acid Composition. The Journal of Biochemistry, 99, 153-162.

[2] Klein, P. (1986) Prediction of Protein Structural Class by Discriminant Analysis. Biochimica et Biophysica Acta, Protein Structure and Molecular Enzymology, 874, 205-215. http://dx.doi.org/10.1016/0167-4838(86)90119-6

[3] Dubchak, I., Muchnik, I., Holbrook, S.R. and Kim, S.H. (1995) Prediction of Protein Folding Class Using Global Description of Amino Acid Sequence. Proceedings of the National Academy of Sciences of the United States of America, 92, 8700-8704. http://dx.doi.org/10.1073/pnas.92.19.8700

[4] Bahar, I., Atilgan, A.R., Jernigan, R.L. and Erman, B. (1997) Understanding the Recognition of Protein Structural Classes by Amino Acid Composition. Proteins, 29, 172-185.

[5] Chou, K.C. (1999) A Key Driving Force in Determination of Protein Structural Classes. Biochemical and Biophysical Research Communications, 264, 216-224. http://dx.doi.org/10.1006/bbrc.1999.1325

[6] Ofran, Y. and Margalit, H. (2006) Proteins of the Same Fold and Unrelated Sequences Have Similar Amino Acid Composition. Proteins: Structure, Function, and Bioinformatics, 64, 275-279. http://dx.doi.org/10.1002/prot.20964

[7] Taguchi, Y. and Gromiha, M.M. (2007) Application of Amino Acid Occurrence for Discriminating Different Folding Types of Globular Proteins. BMC Bioinformatics, 8, 404. http://dx.doi.org/10.1186/1471-2105-8-404

[8] Rackovsky, S. (2009) Sequence Physical Properties Encode the Global Organization of Protein Structure Space. Proceedings of the National Academy of Sciences of the United States of America, 106, 14345-14348. http://dx.doi.org/10.1073/pnas.0903433106

[9] Karlin, S. and Burge, C. (1995) Dinucleotide Relative Abundance Extremes: A Genomic Signature. Trends in Genetics, 11, 283-290. http://dx.doi.org/10.1016/S0168-9525(00)89076-9

[10] Karlin, S., Mrázek, J. and Campbell, A.M. (1997) Compositional Biases of Bacterial Genomes and Evolutionary Implications. Journal of Bacteriology, 179, 3899-3913.

[11] Nakashima, H., Ota, M., Nishikawa, K. and Ooi, T. (1998) Gene from Nine Genomes Are Separated into Their Organisms in the Dinucleotide Composition Space. DNA Research, 5, 251-259. http://dx.doi.org/10.1093/dnares/5.5.251

[12] Bernardi, G., Olofsson, B., Filipski, J., Zerial, M., Salinas, J., Cuny, G., Meunier-Rotival, M. and Rodier, F. (1985) The Mosaic Genome of Warm-Blooded Vertebrates. Science, 228, 953-958. http://dx.doi.org/10.1126/science.4001930

[13] Kreil, D.P. and Ouzounis, C.A. (2001) Identification of Thermophilic Species by the Amino Acid Compositions Deduced from Their Genomes. Nucleic Acids Research, 29, 1608-1615. http://dx.doi.org/10.1093/nar/29.7.1608

[14] Fukuchi, S. and Nishikawa, K. (2001) Protein Surface Amino Acid Compositions Distinctively Differ between Thermophilic and Mesophilic Bacteria. Journal of Molecular Biology, 309, 835-843. http://dx.doi.org/10.1006/jmbi.2001.4718

[15] Chakravarty, S. and Varadarajan, R. (2002) Elucidation of Factors Responsible for Enhanced Thermal Stability of Proteins: A Structural Genomics Based Study. Biochemistry, 41, 8152-8161. http://dx.doi.org/10.1021/bi025523t

[16] Nakashima, H., Fukuchi, S. and Nishikawa, K. (2003) Compositional Changes in RNA, DNA and Proteins for Bacterial Adaptation to Higher and Lower Temperatures. The Journal of Biochemistry, 133, 507-513. http://dx.doi.org/10.1093/jb/mvg067

[17] Yokota, K., Satou, K. and Ohki, S. (2006) Comparative Analysis of Protein Thermostability: Differences in Amino 
Acid Content and Substitution at the Surfaces and in the Core Regions of Thermophilic and Mesophilic Proteins. Science and Technology of Advanced Materials, 7, 255-262.

[18] Murzin, A.G., Brenner, S.E., Hubbard, T. and Chothia, C. (1995) SCOP: A Structural Classification of Proteins Database for the Investigation of Sequences and Structures. Journal of Molecular Biology, 247, 536-540. http://dx.doi.org/10.1016/S0022-2836(05)80134-2

[19] Berman, H.M., Westbrook, J., Feng, Z., Gilliland, G., Bhat, T.N., Weissig, H., Shindyalov, I.N. and Bourne, P.E. (2000) The Protein Data Bank. Nucleic Acids Research, 28, 235-242. http://dx.doi.org/10.1093/nar/28.1.235

[20] Altschul, S.F., Gish, W., Miller, W., Myers, E.W. and Lipman, D.J. (1990) Basic Local Alignment Search Tool. Journal of Molecular Biology, 215, 403-410. http://dx.doi.org/10.1016/S0022-2836(05)80360-2

[21] Kabsch, W. and Sander, C. (1983) Dictionary of Protein Secondary Structure: Pattern Recognition of HydrogenBonded and Geometrical Features. Biopolymers, 22, 2577-2637. http://dx.doi.org/10.1002/bip.360221211

[22] Nishikawa, K. and Ooi, T. (1982) Correlation of the Amino Acid Composition of a Protein to Its Structural and Biological Characters. The Journal of Biochemistry, 91, 1821-1824.

[23] Nishikawa, K., Kubota, Y. and Ooi, T. (1983) Classification of Proteins into Groups Based on Amino Acid Composition and Other Characters. I. Angular Distribution. The Journal of Biochemistry, 94, 981-995.

[24] Nishikawa, K., Kubota, Y. and Ooi, T. (1983) Classification of Proteins into Groups Based on Amino Acid Composition and Other Characters. II. Grouping into Four Types. The Journal of Biochemistry, 94, 997-1007.

[25] Lobry, J.R. (1997) Influence of Genomic G+C Content on Average Amino-Acid Composition of Proteins from 59 Bacterial Species. Gene, 205, 309-316. http://dx.doi.org/10.1016/S0378-1119(97)00403-4

[26] Singer, G.A.C. and Hickey, D.A. (2000) Nucleotide Bias Causes a Genomewide Bias in the Amino Acid Composition of Proteins. Molecular Biology and Evolution, 17, 1581-1588. http://dx.doi.org/10.1093/oxfordjournals.molbev.a026257

[27] Bharanidharan, D., Bhargavi, G.R., Uthanumallian, K. and Gautham, N. (2004) Correlations between Nucleotide Frequencies and Amino Acid Composition in 115 Bacterial Species. Biochemical and Biophysical Research Communications, 315, 1097-1103. http://dx.doi.org/10.1016/j.bbrc.2004.01.129

[28] Hu, J., Zhao, X., Zhang, Z. and Yu, J. (2007) Compositional Dynamics of Guanine and Cytochine Content in Prokaryotic Genomes. Research in Microbiology, 158, 363-370. http://dx.doi.org/10.1016/j.resmic.2007.02.007

[29] Nakashima, H., Yoshihara, A. and Kitamura, K. (2013) Favorable and Unfavorable Amino Acid Residues in Water-Soluble and Transmembrane Proteins. Journal of Biomedical Science and Engineering, 6, 36-44. http://dx.doi.org/10.4236/jbise.2013.61006

[30] Chou, P.Y. and Fasman, G.D. (1978) Empirical Predictions of Protein Conformation. Annual Review of Biochemistry, 47, 251-276. http://dx.doi.org/10.1146/annurev.bi.47.070178.001343 


\section{Supplementary Data}

\begin{tabular}{|c|c|c|c|c|}
\hline E. coli & alpha & & & \\
\hline No. & SCOP & PDB & residues & protein name \\
\hline 1 & A.1.1.2 & 1GVHA1 & 146 & Flavohemoglobin, N-terminal domain \\
\hline 2 & A.1.2.1 & 1KF6B1 & 138 & Fumarate reductase flavoprotein \\
\hline 3 & A.2.14.1 & 1TJLA1 & 104 & DnaK suppressor protein DksA, alpha-hairpin domain \\
\hline 4 & A.4.5.8 & 1B9NA1 & 122 & Transcriptional regulator ModE, N-terminal domain \\
\hline 5 & A.4.5.10 & 2Z9OA1 & 114 & (A: 21 - 143) RepE54 \\
\hline 6 & A.4.5.10 & 1REPC2 & 103 & (C: 144 - 246) RepE54 \\
\hline 7 & A.4.5.10 & 2NRAC1 & 135 & (C: 9 - 151) Replication initiation protein PI \\
\hline 8 & A.4.5.10 & 2NRAC2 & 117 & (C: 152 - 268) Replication initiation protein PI \\
\hline 9 & A.4.5.27 & 1T0FA1 & 100 & (A: 169 - 268) TnsA endonuclease, C-terminal domain \\
\hline 10 & A.4.5.28 & 1JGSA & 138 & Multiple antibiotic resistance repressor \\
\hline 11 & A.4.5.43 & 1OYWA1 & 110 & (A: 407 - 516) DNA helicase RecQ DNA-binding domain \\
\hline 12 & A.4.5.65 & 1T98A1 & 103 & (A: 8 - 118) Chromosome partition protein MukF \\
\hline 13 & A.4.6.1 & 1GXQA & 105 & Transcription activator PhoB \\
\hline 14 & A.4.12.1 & $1 \mathrm{CO} 0 \mathrm{~A}$ & 105 & Trp repressor, TrpR \\
\hline 15 & A.4.14.1 & 1R71B & 114 & Transcriptional repressor protein KorB \\
\hline 16 & A.6.1.3 & 1Q05B & 122 & Transcriptional regulator CueR \\
\hline 17 & A.7.3.1 & 1CHUA1 & 111 & (A: 423 - 533) L-aspartate oxidase \\
\hline 18 & A.7.3.1 & 1NEKA1 & 138 & (A: 451 - 588) Succinate dehydogenase \\
\hline 19 & A.7.15.1 & 1XDOA1 & 105 & Polyphosphate kinase, PPK \\
\hline 20 & A.8.4.1 & 1DKXA1 & 101 & (A: 507 - 607) Chaperone DnaK \\
\hline 21 & A.8.4.1 & 1U00A1 & 112 & (A: 504 - 615) Chaperone protein hscA (Hsc66) \\
\hline 22 & A.8.7.1 & 1R8IA & 187 & Secretion system protein TraC \\
\hline 23 & A.24.2.1 & 2ASRA & 142 & Aspartate receptor, ligand-binding domain \\
\hline 24 & A.24.3.1 & 1APCA & 106 & Cytochrome b562 \\
\hline 25 & A.24.10.1 & 2A0BA & 118 & Aerobic respiration control sensor protein \\
\hline 26 & A.24.10.4 & 1SR2A & 116 & Sensor-like histidine kinase YojN, C-terminal domain \\
\hline 27 & A.25.1.1 & 1BFRA & 158 & Bacterioferritin (Cytochrome b1) \\
\hline 28 & A.25.1.1 & 1DPSA & 159 & Dodecameric ferritin homolog \\
\hline 29 & A.25.1.2 & 1OTKA & 244 & Phenylacetic acid degradation protein PaaC \\
\hline 30 & A.25.1.2 & 1MXRA & 339 & Ribonucleotide reductase R2 \\
\hline 31 & A.24.16.4 & 1V4AA1 & 151 & (A: 287 - 437) Glutamine synthase adenylyltransferase \\
\hline 32 & A.25.1.4 & 2GS4A1 & 158 & Hypothetical protein YciF \\
\hline 33 & A.27.1.1 & 1U0BB1 & 146 & (B: 316 - 461) Cysteinyl-tRNA synthetase (CysRS) \\
\hline 34 & A.29.15.1 & 2HI7B1 & 134 & Disulfide bond formation protein \\
\hline
\end{tabular}




\section{Continued}

\begin{tabular}{|c|c|c|c|c|}
\hline 35 & A.29.17.1 & 2HGKA1 & 109 & Hypothetical protein YqcC \\
\hline 36 & A.43.1.5 & 1CMCA & 104 & Met repressor, MetJ \\
\hline 37 & A.45.1.1 & 1N2AA1 & 121 & (A: 81 - 201) class beta GST \\
\hline 38 & A.45.1.1 & 1B8XA1 & 180 & (A: 81 - 260) class beta GST \\
\hline 39 & A.45.1.1 & 1G7OA1 & 140 & (A: 76 - 215) Glutaredoxin 2 \\
\hline 40 & A.60.8.3 & 1YT3A1 & 101 & (A: 194 - 294) Ribonuclease D \\
\hline 41 & A.60.10.1 & 1EZAA1 & 123 & (A: 22 - 144) Enzyme I of the PEP \\
\hline 42 & A.60.16.1 & 3CI0K2 & 108 & (K: 94 - 203) Pseudopilin GspK \\
\hline 43 & A.70.1.1 & 1ABVA & 105 & ATP synthase delta subunit, N-terminal domain \\
\hline 44 & A.78.1.1 & 1E2XA2 & 149 & Fatty acid responsive transcription factor \\
\hline 45 & A.79.1.3 & 1SQFA1 & 140 & Ribosomal RNA small subunit methyltransferase \\
\hline 46 & A.80.1.1 & 1JR3A1 & 126 & (A: 243 - 368) DNA polymerase gamma subunit \\
\hline 47 & A.80.1.1 & 1A5TA1 & 116 & (A: 208 - 330) Delta prime subunit \\
\hline 48 & A.81.1.1 & 1JWEA & 114 & DnaB helicase N-terminal domain \\
\hline 49 & A.92.1.1 & 1A9XA1 & 153 & (A: 403 - 555) Carbamoyl phosphate synthetase \\
\hline 50 & A.96.1.2 & $1 \mathrm{KG} 2 \mathrm{~A}$ & 224 & Adenine glycosylase catalytic domain, MutY \\
\hline 51 & A.96.1.3 & 1DIZA1 & 183 & (A: 100 - 282) 3-Methyladenine DNA glycosylase II \\
\hline 52 & A.96.1.4 & 1NKUA & 187 & 3-Methyladenine DNA glycosylase I (tag) \\
\hline 53 & A.98.1.1 & 5R1RA1 & 221 & Ribonucleotide reductase R1 subunit \\
\hline 54 & A.100.1.7 & 1KS9A1 & 124 & (a: 168 - 291) Ketopantoate reductase PanE \\
\hline 55 & A.102.1.9 & 2JF4A1 & 500 & (a: 37 - 547) Periplasmic trehalase TreA \\
\hline 56 & A.113.1.1 & 1WB9A1 & 297 & (a: 270 - 566) DNA repair protein MutS, domain III \\
\hline 57 & A.118.1.16 & 1OYZA & 151 & Hypothetical protein YibA \\
\hline 58 & A.118.5.1 & 1QSAA1 & 450 & (a: 1 - 450) $70 \mathrm{KDa}$ soluble lytic transglycosylase \\
\hline 59 & A.118.8.1 & 1XNFB & 259 & Lipoprotein NlpI \\
\hline 60 & A.118.8.2 & 1HZ4A & 366 & Transcription factor Malt domain III \\
\hline 61 & A.118.15.1 & 1L5JA1 & 160 & Aconitase B, N-terminal domain \\
\hline 62 & A.121.1.1 & 2VKVA2 & 138 & (a: 68 - 205) Tetracyclin repressor protein \\
\hline 63 & A.127.1.1 & 1TJ7A & 455 & Argininosuccinate lyase/delta-crystallin \\
\hline 64 & A.128.1.1 & 1RQIA & 300 & Farnesyl diphosphate synthase \\
\hline 65 & A.129.1.1 & 1AONA1 & 135 & (a: 2 - 136, a: 410 - 525) GroEL, E domain \\
\hline 66 & A.136.1.1 & 1DVOA & 152 & Repressor of bacterial conjugation Fino \\
\hline 67 & A.138.1.3 & 1GU6A & 441 & Cytochrome c nitrite reductase \\
\hline 68 & A.174.1.1 & 1R6OA1 & 142 & N-terminal, clps-binding domain of ClpA \\
\hline 69 & A.177.1.1 & 1OR7A2 & 113 & RNA polymerase sigma E factor (RpoE) \\
\hline 70 & A.177.1.1 & 1SIGA & 205 & RNA polymerase sigma factor Sigma70 \\
\hline
\end{tabular}




\section{Continued}

\begin{tabular}{|c|c|c|c|c|}
\hline 71 & A.198.1.1 & 1QZ4A & 213 & Hypothetical protein YcfC \\
\hline 72 & A.211.1.1 & 2PAQA1 & 177 & 5'-nucleotidase YfbR \\
\hline 73 & A.211.1.5 & 1U6ZA1 & 197 & (A: 313 - 509) Exopolyphosphatase Ppx C-terminal \\
\hline 74 & A.223.1.1 & 1W26A1 & 185 & (A: 248 - 432) Trigger factor, C-terminal domain \\
\hline 75 & A.223.1.2 & 1M5YA1 & 140 & (A: 25 - 164, a: 395 - 427) Porin chaperone SurA \\
\hline 76 & A.233.1.1 & 1WPBA & 168 & Hypothetical protein YfbU \\
\hline 77 & A.236.1.1 & 1T3WB & 134 & DNA primase DnaG, C-terminal domain \\
\hline \multicolumn{5}{|c|}{ T. maritime } \\
\hline 1 & A.4.5.28 & 2A61A1 & 139 & Transcriptional regulator TM0710 \\
\hline 2 & A.4.5.61 & 2ESHA1 & 114 & Hypothetical protein TM0937 \\
\hline 3 & A.7.12.1 & 1SUMB & 224 & PhoU homolog TM1734 \\
\hline 4 & A.8.3.3 & 2B5DX1 & 114 & (X: 415 - 528) Alpha-amylase AmyC \\
\hline 5 & A. 24.10 .3 & 1TQGA & 105 & Chemotaxis protein CheA P1 domain \\
\hline 6 & A.24.16.3 & 1O3UA & 120 & Hypothetical protein TM0613 \\
\hline 7 & A.24.25.1 & 1XZPA1 & 172 & (A: 118 - 211, A: 372 - 450) TrmE connector domain \\
\hline 8 & A.24.29.1 & 2P61A1 & 113 & Hypothetical protein TM1646 \\
\hline 9 & A.25.1.1 & 1VJXA & 144 & Hypothetical protein TM1526 \\
\hline 10 & A.25.1.1 & 1VLGA & 164 & Non-hem ferritin \\
\hline 11 & A.29.9.1 & 2ETDA1 & 118 & Hypothetical protein TM0961 \\
\hline 12 & A.60.13.1 & 1M6YA1 & 101 & (A: 115 - 215) Putative methyltransferase TM0872 \\
\hline 13 & A.79.1.1 & 1TZVA & 141 & Antitermination factor NusB \\
\hline 14 & A.100.1.10 & 2I76A1 & 103 & (A: 155 - 257) Hypothetical protein TM1727 \\
\hline 15 & A.118.14.1 & 1LKVX & 213 & Flgellar motor switch protein FliG \\
\hline 16 & A.121.1.1 & 1Z77A2 & 122 & (A: 76 - 200) Transcriptional regulator TM1030 \\
\hline 17 & A.127.1.1 & 1C3UA & 422 & Adenylosuccinate lyase \\
\hline 18 & A.128.1.1 & 1V4EA & 280 & Octoprenyl-diphosphate synthase \\
\hline 19 & A.149.1.1 & 1O0WA1 & 169 & Rnase III endonuclease catalytic domain \\
\hline 20 & A.152.1.2 & 1P8CE & 111 & Hypothetical protein TM1620 \\
\hline 21 & A.191.1.1 & $105 \mathrm{HA}$ & 200 & Hypothetical protein TM1560 \\
\hline 22 & A.269.1.1 & 2CE7A1 & 162 & Cell division protein FtsH, C-terminal domain \\
\hline \multicolumn{5}{|c|}{ T. thermophilus } \\
\hline 1 & A.3.1.1 & $1 \mathrm{C} 52 \mathrm{~A}$ & 131 & Cytochrome c552 \\
\hline 2 & A.3.1.5 & 1NMLA1 & 166 & (1 - 166) Di-heme cytochrome c peroxidase \\
\hline 3 & A.3.1.5 & 1NMLA2 & 150 & (167 - 326) Di-heme cytochrome c peroxidase \\
\hline 4 & A.22.1.4 & 1WWIA1 & 145 & Hypothetical protein tha1479 \\
\hline 5 & A.24.16.2 & 1WTYA & 116 & Probable nucleotidyltransferase subunit \\
\hline
\end{tabular}




\section{Continued}

\begin{tabular}{|c|c|c|c|c|}
\hline 6 & A.25.1.3 & 2CWLA1 & 299 & Manganese catalase \\
\hline 7 & A.27.1.1 & 1IQ0A1 & 126 & (a: 467 - 592) Arginyl-tRNA synthetase \\
\hline 8 & A.27.1.1 & 1ILEA1 & 180 & (a: 642 - 821) Isoleucyl-tRNA synthetase \\
\hline 9 & A.27.1.1 & 1A8HA1 & 152 & (a: 349 - 500) Methionyl-tRNA synthetase \\
\hline 10 & A.29.3.1 & 1WS9A1 & 153 & (a: 235 - 387) Acyl-CoA dehydrogenase \\
\hline 11 & A.29.12.1 & 2FUG11 & 105 & (1: 334 - 438) NADH-quinone oxidoreductase chain 1 \\
\hline 12 & A.75.1.1 & 1FJGG & 155 & $16 \mathrm{~S}$ ribosomal protein $\mathrm{S} 7$ \\
\hline 13 & A.97.1.1 & 1G59A1 & 163 & (a: 306 - 468) C-terminal Glutamyl-tRNA synthetase \\
\hline 14 & A.99.1.1 & 1IQRA1 & 245 & (a: 172 - 416) C-terminal domain of DNA photolyase \\
\hline 15 & A.103.1.1 & 1IOMA & 374 & Citrate synthase \\
\hline 16 & A.104.1.1 & 1N97A & 385 & Electron transport molecule cyp175a1 \\
\hline 17 & A.118.26.1 & 2YVXA1 & 125 & Magnesium transporter mgte \\
\hline 18 & A.127.1.1 & 1VDKA & 458 & Fumarase \\
\hline 19 & A.132.1.3 & 1WWMA1 & 180 & Hypothetical protein tha0169 \\
\hline 20 & A.144.2.1 & 1VSAO1 & 117 & Ribosomal protein L20 \\
\hline 21 & A.152.1.4 & 2CWQA1 & 116 & Hypothetical protein ttha0727 \\
\hline 22 & A.156.1.1 & 1FJGM & 125 & Ribosomal protein S13 \\
\hline 23 & A.174.1.1 & 1QVRA1 & 145 & $\mathrm{~N}$-terminal domain of clpb, chaperone \\
\hline \multicolumn{5}{|c|}{ Human } \\
\hline 1 & A.1.1.2 & 1AJ9B & 146 & Hemoglobin, beta-chain \\
\hline 2 & A.4.1.18 & 2DW4A1 & 102 & (A: 172 - 273) Lysine-specific histone demethylase 1 \\
\hline 3 & A.4.3.1 & 1IG6A & 107 & MRF-2 DNA-binding domain \\
\hline 4 & A.4.3.1 & 1RYUA & 120 & SWI-SNF complex protein p270 \\
\hline 5 & A.4.5.23 & $1 \mathrm{~T} 2 \mathrm{KA}$ & 110 & Interferon regulatory factor 3 \\
\hline 6 & A.4.5.31 & 2CSOA1 & 115 & (A: 8 - 122) Pleckstrin \\
\hline 7 & A.4.5.43 & 2AXLA1 & 144 & Werner syndrome ATP-dependent helicase WRN \\
\hline 8 & A.4.5.46 & 1S7AA & 103 & Lupus La autoantigen N-terminal domain \\
\hline 9 & A.5.6.1 & 2CRUA1 & 105 & programmed cell death protein 5 \\
\hline 10 & A.6.1.4 & 1L8RA & 101 & Retinal determination protein Dachshund \\
\hline 11 & A.7.1.1 & 1OWAA & 156 & Spectrin alpha chain \\
\hline 12 & A.7.1.1 & 1S35A2 & 105 & (A: 1169 - 1273) Spectrin beta chain \\
\hline 13 & A.7.1.1 & 1S35A1 & 106 & (A: 1063 - 1168) Spectrin beta chain \\
\hline 14 & A.7.1.1 & 1HCIA1 & 125 & (A: 272 - 396) alpha-actinin \\
\hline 15 & A.7.1.1 & 1HCIA2 & 115 & (A: 397 - 511) alpha-actinin \\
\hline 16 & A.7.1.1 & 1HCIA3 & 121 & (A: 512 - 632) alpha-actinin \\
\hline 17 & A.7.1.1 & 1HCIA4 & 114 & (A: 633 - 746) alpha-actinin \\
\hline 18 & A.7.4.1 & 1FEWA & 173 & Smac/diablo \\
\hline
\end{tabular}




\section{Continued}

\begin{tabular}{|c|c|c|c|c|}
\hline 19 & A.7.8.1 & 1NAFA & 124 & ADP-ribosylation factor binding protein Gga1 \\
\hline 20 & A.7.11.1 & 1W0BA & 102 & Alpha-hemoglobin stabilizing protein \\
\hline 21 & A.7.14.1 & 2CPTA1 & 104 & (A: 8 - 111) Vacuolar sorting protein 4b \\
\hline 22 & A.11.2.1 & 1H4RA1 & 111 & (A: 104 - 214) Merlin \\
\hline 23 & A.13.1.1 & 2FTUA1 & 118 & alpha-2-Macroglobulin receptor associated protein \\
\hline 24 & A.22.1.1 & 2CV5C1 & 108 & Histone H2A \\
\hline 25 & A.22.1.3 & 1JFIB & 135 & Negative cofactor 2, beta chain \\
\hline 26 & A.24.1.1 & 1EA8A & 140 & Apolipoprotein E \\
\hline 27 & A.24.9.1 & 1RKCA1 & 128 & Vinculin \\
\hline 28 & A.24.9.1 & 1RKCA2 & 129 & (A: 129 - 258) Vinculin \\
\hline 29 & A.24.14.1 & $1 \mathrm{~K} 05 \mathrm{~A}$ & 135 & FAT domain of focal adhesion kinase \\
\hline 30 & A.26.1.1 & $1 \mathrm{CNT} 1$ & 150 & Ciliary neurotrophic factor \\
\hline 31 & A.26.1.1 & 1ALUA & 157 & Interleukin-6 \\
\hline 32 & A.26.1.1 & 1CD9A & 171 & Granulocyte-colony stimulating factor \\
\hline 33 & A.26.1.1 & 1F45B & 133 & Heterodimeric interleukin-12 alpha chain \\
\hline 34 & A.26.1.2 & 1HULA & 108 & Interleukin-5 \\
\hline 35 & A.26.1.2 & 1IJZA & 113 & Interleukin-13 \\
\hline 36 & A.26.1.2 & $1 \mathrm{M} 47 \mathrm{~A}$ & 122 & Interleukin-2 \\
\hline 37 & A.26.1.2 & 1BUYA & 166 & Erythropoietin \\
\hline 38 & A.26.1.2 & 2OQPA1 & 133 & Interleukin-21 \\
\hline 39 & A.26.1.3 & 1N1FA & 153 & Interleukin-19 \\
\hline 40 & A.26.1.3 & 1AU1A & 166 & Interferon-beta \\
\hline 41 & A.26.1.3 & 1EKUA1 & 122 & Interferon-gamma \\
\hline 42 & A.29.5.1 & 1Y8NA1 & 164 & (A: 13 - 176) Pyruvate dehydrogenase kinase \\
\hline 43 & A.29.7.1 & 1PI1A & 185 & Mob1a \\
\hline 44 & A.29.10.1 & 1V9VA1 & 101 & Microtubule-associated Ser/Thr-protein kinase \\
\hline 45 & A.35.1.7 & 1WH8A & 111 & Homeobox protein Cux-2 \\
\hline 46 & A.35.1.7 & 1WIZA & 101 & DNA-binding protein SATB2 \\
\hline 47 & A.39.1.2 & $1 \mathrm{M} 31 \mathrm{~A}$ & 101 & Calcyclin (S100) \\
\hline 48 & A.39.1.4 & 1RJVA & 110 & Parvalbumin \\
\hline 49 & A.39.1.5 & 1DGUA & 183 & Calcium- and integrin-binding protein \\
\hline 50 & A.39.1.6 & 1IQ3A & 110 & Pob1 \\
\hline 51 & A.39.1.7 & 1EG3A1 & 125 & (A: 85 - 209) Dystrophin \\
\hline 52 & A.39.1.7 & 1TUZA & 118 & Diacylglycerol kinase alpha, N-terminal domain \\
\hline 53 & A.39.1.7 & 2FJUB1 & 141 & (B: 142 - 311) Phospholipase C-beta-2 \\
\hline 54 & A.39.1.8 & 1KFUL1 & 186 & Calpain large subunit, C-terminal domain \\
\hline 55 & A.40.1.1 & 1WJOA & 124 & Fimbrin (Plastin), actin-crosslinking domain \\
\hline
\end{tabular}




\section{Continued}

\begin{tabular}{|c|c|c|c|c|}
\hline 56 & A.40.1.1 & 1DXXA1 & 111 & (A: 9 - 119) Dystrophin \\
\hline 57 & A.40.1.1 & 1DXXB2 & 127 & (B: 120 - 246) Dystrophin \\
\hline 58 & A.40.1.1 & 1UEGA & 119 & Microtubule-associated protein eb1, N-domain \\
\hline 59 & A.41.1.1 & 1UK0A1 & 137 & Domain of poly(ADP-ribose) polymerase \\
\hline 60 & A.45.1.1 & 1EEMA1 & 139 & (A: 103 - 241) Class omega GST \\
\hline 61 & A.45.1.1 & 1GSEA1 & 142 & (A: 81 - 222) Class alpha GST \\
\hline 62 & A.45.1.1 & 1IYHA1 & 124 & (A: 76 - 199) Class sigma GST \\
\hline 63 & A.45.1.1 & 1K0MA1 & 149 & (A: 92 - 240) Chloride intracellular channel 1 \\
\hline 64 & A.47.1.1 & 1BF5A1 & 167 & (A: 136 - 316) STAT-1, coiled coil domain \\
\hline 65 & A.48.1.1 & 1YVHA2 & 130 & (A: 48 - 177) N-terminal domain of cbl \\
\hline 66 & A.48.2.1 & 1CX8A1 & 152 & Transferrin receptor ectodomain, C-terminal domain \\
\hline 67 & A.60.7.1 & 1UL1X1 & 140 & (X: 218 - 357) Flap endonuclease-1 \\
\hline 68 & A.60.8.1 & 2DGZA1 & 100 & Werner syndrome ATP-dependent helicase \\
\hline 69 & A.60.8.4 & 2CPRA1 & 113 & (A: 483 - 595) Exosome component 10 \\
\hline 70 & A.65.1.1 & 1W7BA & 319 & Annexin II \\
\hline 71 & A.66.1.1 & 2EBCA1 & 121 & Transducin (alpha subunit), insertion domain \\
\hline 72 & A.68.1.1 & $1 \mathrm{EJ} 5 \mathrm{~A}$ & 107 & Wiscott-Aldrich syndrome protein, C-terminal domain \\
\hline 73 & A.74.1.1 & 1E9HB2 & 123 & (B: 310 - 432) Cyclin A \\
\hline 74 & A.74.1.1 & 2I53A2 & 110 & (A: 158 - 267) Cyclin K \\
\hline 75 & A.74.1.1 & 2I53A1 & 144 & (A: 14 - 157) Cyclin K \\
\hline 76 & A.74.1.1 & 1JKWA1 & 151 & (A: 11 - 161) Cyclin $\mathrm{H}$ \\
\hline 77 & A.74.1.1 & 1JKWA2 & 126 & (A: 162 - 287) Cyclin H \\
\hline 78 & A.74.1.1 & 1W98B1 & 130 & (B: 228 - 357) G1/S-specific cyclin-E1 \\
\hline 79 & A.74.1.1 & 1W98B2 & 140 & (B: 88 - 227) G1/S-specific cyclin-E1 \\
\hline 80 & A.74.1.2 & 1C9BA2 & 109 & (A: 208 - 316) Transcription factor IIB, core domain \\
\hline 81 & A.74.1.3 & 1GUXA & 177 & Retinoblastoma tumor suppressor domains \\
\hline 82 & A.77.1.2 & 1DDFA & 125 & Fas \\
\hline 83 & A.77.1.2 & 1E3YA & 104 & Fadd (Mort1) \\
\hline 84 & A.77.1.3 & 1CWWA & 102 & Apoptotic protease activating factor 1 \\
\hline 85 & A.77.1.3 & 3CRDA & 100 & Raidd CARD domain \\
\hline 86 & A.83.1.1 & 1QK1A1 & 102 & Creatine kinase, $\mathrm{N}$-domain \\
\hline 87 & A.87.1.1 & 1TXDA1 & 234 & Rho guanine nucleotide exchange factor 12 \\
\hline 88 & A.87.1.1 & 1DBHA1 & 207 & (A: 198 - 404) Son of sevenless-1 \\
\hline 89 & A.91.1.1 & 1DK8A & 147 & Axin RGS-homologous domain \\
\hline 90 & A.91.1.1 & 1IAPA & 190 & p115 RhoGEF \\
\hline 91 & A.100.1.3 & 1F12A1 & 101 & Short chain L-3-hydroxyacyl CoA dehydrogenase \\
\hline 92 & A.102.4.2 & 1W6JA2 & 279 & (A: 100 - 378) Lanosterol synthase \\
\hline
\end{tabular}




\section{Continued}

\begin{tabular}{|c|c|c|c|c|}
\hline 93 & A.102.4.3 & 1JCQB & 410 & Protein farnesyltransferase, beta-subunit \\
\hline 94 & A.102.4.4 & 1GHQA & 307 & a C3 fragment and ligand for complement receptor \\
\hline 95 & A.114.1.1 & 1DG3A1 & 300 & Interferon-induced guanylate-binding protein 1 \\
\hline 96 & A.116.1.1 & 1GRNB & 197 & Cdc42GAP \\
\hline 97 & A.116.1.1 & 1PBWA & 184 & p85 alpha subunit RhoGAP domain \\
\hline 98 & A.116.1.2 & 1WERA & 324 & p120GAP domain \\
\hline 99 & A.117.1.1 & 1NVUS & 469 & Son of sevenless protein homolog 1 \\
\hline 100 & A.118.1.1 & $1 \mathrm{~T} 08 \mathrm{~A}$ & 510 & beta-Catenin \\
\hline 101 & A.118.1.2 & 2IE3A1 & 581 & Phosphatase 2, Constant regulatory domain \\
\hline 102 & A.118.1.6 & 1E8YA1 & 186 & Phoshoinositide 3-kinase helical domain \\
\hline 103 & A.118.1.7 & 1GW6A1 & 150 & (A: 461 - 610) Leukotriene A4 hydrolase C-domain \\
\hline 104 & A.118.1.8 & 1M8WA & 340 & Pumilio 1, RNA binding protein \\
\hline 105 & A.118.1.14 & 1Н2ТC3 & 251 & (C: 481 - 790) CBP80, 80 KDa nuclear cap-binding protein \\
\hline 106 & A.118.1.14 & 1UG3A1 & 193 & (A: 1235 - 1427) Eukaryotic initiation factor elf4G \\
\hline 107 & A.118.1.14 & 1UG3A2 & 127 & (A: 1438 - 1564) Eukaryotic initiation factor elF4G \\
\hline 108 & A.118.1.14 & $1 \mathrm{HU} 3 \mathrm{~A}$ & 204 & Eukaryotic initiation factor eIF4G \\
\hline 109 & A.118.1.14 & 1Н2TC2 & 190 & CBP80, 80 KDa nuclear cap-binding protein \\
\hline 110 & A.118.1.14 & 1H2UA1 & 265 & CBP80, 80 KDa nuclear cap-binding protein \\
\hline 111 & A.118.1.18 & 1RZ4A2 & 130 & Eukaryotic translation initiation factor 3 \\
\hline 112 & A.118.1.19 & 1W9CA & 321 & Exportin-1 (Xpo1, Crm1) \\
\hline 113 & A.118.1.20 & 2JAKA1 & 327 & Serine/threonine-protein phosphatase 2A \\
\hline 114 & A.118.1.21 & 1XQRA1 & 264 & (A: 87 - 350) Hsp70-binding protein 1 \\
\hline 115 & A.118.6.1 & 1JCQA & 313 & Protein farnesyltransferase alpha-subunit \\
\hline 116 & A.118.7.1 & 1QJAA & 217 & zeta isoform \\
\hline 117 & A.118.8.1 & 1ELRA & 128 & Hop \\
\hline 118 & A.118.8.1 & 1YA0A1 & 458 & SMG-7 transcript variant 2 \\
\hline 119 & A.118.8.1 & 1KT0A1 & 155 & (A: 254 - 412) FKBP51, C-terminal domain \\
\hline 120 & A.118.9.1 & $1 \mathrm{INZA}$ & 148 & Epsin 1, Eps15-interacting protein \\
\hline 121 & A.118.9.2 & 1ELKA & 153 & Tom1 protein \\
\hline 122 & A.118.12.1 & 2GRNB1 & 157 & Ran-GTPase activating protein 1, C-domain \\
\hline 123 & A.118.16.1 & 1J1JA & 217 & Translin \\
\hline 124 & A.118.17.1 & 2HYEC2 & 347 & (C: 55 - 401) Cullin-4A \\
\hline 125 & A.118.19.1 & 1RW2A & 152 & C-terminal domain of Ku80 \\
\hline 126 & A.118.23.1 & 2A9UA1 & 134 & Ubiquitin carboxyl-terminal hydrolase 8 \\
\hline 127 & A.123.1.1 & 1P93A & 247 & Glucocorticoid receptor \\
\hline 128 & A.123.1.1 & $1 \mathrm{LV} 2 \mathrm{~A}$ & 225 & Hepatocyte nuclear factor 4-gamma \\
\hline 129 & A.123.1.1 & 1EXAA & 236 & Retinoic acid receptor gamma \\
\hline
\end{tabular}




\section{Continued}

\begin{tabular}{|c|c|c|c|c|}
\hline 130 & A.126.1.1 & 1J78A2 & 188 & (A: 199 - 386) Vitamin D binding protein \\
\hline 131 & A.128.1.2 & 1EZFA & 323 & Squalene synthase \\
\hline 132 & A.132.1.1 & 1N3UA & 214 & Heme oxygenase-1 (HO-1) \\
\hline 133 & A.143.1.2 & 1QKLA & 127 & RPB6 \\
\hline 134 & A.144.1.1 & 1G9LA & 144 & poly(A) binding protein \\
\hline 135 & A.146.1.1 & 1H6OA & 195 & Telomeric repeat binding factor 1 , TRF1 \\
\hline 136 & A.156.1.2 & 1TDHA1 & 110 & (A: 132 - 246) Endonuclease VIII-like 1 \\
\hline 137 & A.158.1.1 & 1P22A1 & 109 & (A: 135 - 252) F-box/WD-repeat protein 1 \\
\hline 138 & A.169.1.1 & 1MI1A1 & 305 & (A: 2249 - 2553) BEACH domain of neurobeachin \\
\hline 139 & A.173.1.1 & 1OU5A1 & 204 & (A: 151 - 354) tRNA CCA-adding enzyme, c-domain \\
\hline 140 & A.183.1.1 & 2OZBB1 & 239 & U4/U6 small nuclear ribonucleoprotein Prp31 \\
\hline 141 & A.188.1.1 & 1MP1A & 111 & Ser/Arg-related nuclear matrix protein \\
\hline 142 & A.211.1.2 & 1MKDA & 328 & Cyclic nucleotide phosphodiesterase catalytic domain \\
\hline 143 & A.224.1.1 & 1SX6A & 205 & Glycolipid transfer protein, GLTP \\
\hline 144 & A.235.1.1 & 1X9NA1 & 264 & (A: 262 - 533) DNA ligase I \\
\hline 145 & A.238.1.1 & 1X03A1 & 210 & (A: 26 - 247) Endophilin-1 \\
\hline 146 & A.238.1.1 & 2ELBA1 & 258 & (A: 6 - 273) DCC-interacting protein 13-alpha \\
\hline 147 & A.238.1.2 & $1 \mathrm{I} 49 \mathrm{~A}$ & 201 & Arfaptin, Rac-binding fragment \\
\hline 148 & A.238.1.4 & 2EFKA1 & 272 & (A: 10 - 288) CDC42-interacting protein 4, CIP4 \\
\hline 149 & A.266.1.2 & 2D0TA1 & 373 & (A: 12 - 403) Indoleamine 2,3-dioxygenase \\
\hline 150 & A.268.1.1 & 2G62A1 & 295 & Serine/threonine-protein phosphatase 2A \\
\hline 151 & A.278.1.1 & 2E9XA1 & 144 & DNA replication complex GINS protein PSF1 \\
\hline 152 & A.278.1.2 & 2Q9QA1 & 112 & DNA replication complex GINS protein PSF2 \\
\hline 153 & A.283.1.1 & 2FMME1 & 116 & (E: 9 - 124) Emsy \\
\hline 154 & A.289.1.1 & 2Q0ZX1 & 176 & (X: 33 - 208) Protein pro2281 \\
\hline \multicolumn{5}{|l|}{ Yeast } \\
\hline 1 & A.2.17.2 & 2F6MB1 & 104 & Vacuolar protein sorting-associated protein 28 \\
\hline 2 & A.3.1.1 & 1CHHA & 108 & Mitochondrial cytochrome c \\
\hline 3 & A.3.1.3 & 1EZVD1 & 199 & Cytochrome bc1 domain \\
\hline 4 & A.4.1.6 & 1IGNA2 & 103 & (A: 446 - 594) DNA-binding domain of rap1 \\
\hline 5 & A.4.3.1 & $1 \mathrm{KKXA}$ & 102 & Transcription regulator Adr6 (Swi1) \\
\hline 6 & A.5.4.1 & 1ENWA & 114 & Elongation factor TFIIS domain 2 \\
\hline 7 & A.7.5.1 & 1QSDA & 102 & Tubulin chaperone cofactor A \\
\hline 8 & A.24.10.2 & $1 \mathrm{C} 03 \mathrm{~A}$ & 163 & Phosphorelay protein ypd1 \\
\hline 9 & A.24.15.1 & 1JR8A & 102 & Thiol oxidase Erv2p \\
\hline 10 & A.25.1.2 & $1 \mathrm{JK} 0 \mathrm{~A}$ & 334 & Ribonucleotide reductase R2 \\
\hline 11 & A.29.2.1 & 1E6IA & 110 & Transcriptional activator GCN5 \\
\hline
\end{tabular}




\section{Continued}

\begin{tabular}{|c|c|c|c|c|}
\hline 12 & A.39.1.5 & $1 \mathrm{M} 46 \mathrm{~A}$ & 148 & Myosin light chain MIc1p \\
\hline 13 & A.39.1.5 & 1FPWA & 190 & Frequenin (neuronal calcium sensor 1) \\
\hline 14 & A.45.1.1 & 1G6WA1 & 133 & Prion protein ure2p, nitrogen regulation fragment \\
\hline 15 & A.45.1.1 & 1NHYA1 & 140 & Elongation factor 1-gamma, GST-like domain \\
\hline 16 & A.45.1.2 & 2HQTA1 & 115 & GU4 nucleic-binding protein 1, Arc1p \\
\hline 17 & A.47.2.1 & $1 \mathrm{FIOA}$ & 190 & Sso1 \\
\hline 18 & A.60.8.2 & $1 \mathrm{Y} 14 \mathrm{~A}$ & 133 & RNA polymerase II subunit RBP4 (RpoF) \\
\hline 19 & A.60.9.1 & 1FLOA1 & 123 & Flp recombinase \\
\hline 20 & A.69.2.1 & 1FKMA1 & 194 & (A: 249 - 442) Ypt/Rab-GAP domain of gyp1p \\
\hline 21 & A.69.2.1 & 1FKMA2 & 128 & (A: 443 - 630) Ypt/Rab-GAP domain of gyp1p \\
\hline 22 & A.71.2.1 & 1M2OA1 & 103 & (A: 524 - 626) Sec23 \\
\hline 23 & A.71.2.1 & 1M2VB1 & 107 & (B: 647 - 753) Sec24 \\
\hline 24 & A.72.1.1 & 1DVKA & 149 & Functional domain of the splicing factor Prp18 \\
\hline 25 & A.80.1.1 & 1SXJA1 & 146 & (A: 548 - 693) Replication factor C1 \\
\hline 26 & A.93.1.1 & 1CYFA & 296 & Cytochrome c peroxidase \\
\hline 27 & A.102.2.1 & 1DL2A & 510 & Class I alpha-1;2-mannosidase, catalytic domain \\
\hline 28 & A.118.1.1 & 1WA5C & 937 & Exportin Cse1p \\
\hline 29 & A.118.1.1 & 1WA5B & 463 & Karyopherin alpha \\
\hline 30 & A.118.1.9 & 1HO8A & 447 & Regulatory subunit $\mathrm{H}$ of the V-type ATPase \\
\hline 31 & A.118.1.14 & 1PAQA & 161 & Translation initiation factor eIF-2b epsilon \\
\hline 32 & A.118.3.1 & 1RE0B & 195 & ARF guanine-exchange factor 1 \\
\hline 33 & А.118.8.1 & 1Y8MA1 & 138 & Mitochondria fission protein Fis1 \\
\hline 34 & A.118.8.1 & 1QQEA & 281 & Vesicular transport protein sec17 \\
\hline 35 & A.118.9.4 & 1SZAA & 144 & PCF11 protein \\
\hline 36 & A.118.17.2 & 2D2SA1 & 217 & (A: 525 - 753) Exocyst complex component EXO84 \\
\hline 37 & A.118.17.2 & 2B7MA1 & 513 & (A: 73 - 623) Exocyst complex component EXO70 \\
\hline 38 & A.130.1.2 & 1CSMA & 252 & Allosteric chorismate mutase \\
\hline 39 & A.158.1.1 & 1NEXB1 & 100 & (B: 270 - 369) Cdc4 F-box and linker domains \\
\hline 40 & A.160.1.1 & 1FA0A3 & 150 & (A: 202 - 351) Poly(A) polymerase, middle domain \\
\hline 41 & А.207.1.1 & 1UX5A & 411 & Bni1 \\
\hline 42 & A.210.1.1 & 1RF8B & 100 & Eukaryotic initiation factor $4 \mathrm{f}$ subunit eIF4g \\
\hline 43 & A.227.1.1 & 1RP4A & 374 & Endoplasmic oxidoreductin 1, Ero1p \\
\hline 44 & A.232.1.1 & 1XLYA & 224 & RNA-binding protein She2p \\
\hline 45 & A.252.1.1 & 1YKEB1 & 119 & RNA polymerase II holoenzyme component SRB7 \\
\hline
\end{tabular}




\begin{tabular}{|c|c|c|c|c|}
\hline E. coli & beta proteins & & & \\
\hline No. & SCOP & PDB & residues & protein name \\
\hline 1 & B.1.4.1 & 1BGLA2 & 105 & (A: 626 - 730) beta-Galactosidase, domain 4 \\
\hline 2 & B.1.4.1 & 1BGLA1 & 114 & (A: 220 - 333) beta-Galactosidase, domain 2 \\
\hline 3 & B.1.11.1 & 1N0LA1 & 124 & Pilus chaperone PapD, N-domain \\
\hline 4 & B.1.17.1 & 1VRSA1 & 121 & Thiol:disulfide interchange protein, DsbD-alpha \\
\hline 5 & B.1.18.2 & 1M7XA1 & 110 & 1,4-alpha-glucan branching enzyme N-terminal domain \\
\hline 6 & B.1.18.2 & 1TXKA1 & 115 & (A:397-511) Glucans biosynthesis protein G \\
\hline 7 & B.1.18.17 & 1IX2B & 102 & Copper resistance protein C (CopC, PcoC) \\
\hline 8 & B.2.3.2 & 2AXWA1 & 121 & Invasin AfaD \\
\hline 9 & B.2.3.2 & 2UY6B1 & 150 & Pap fimbrial major pilin protein PapA \\
\hline 10 & B.2.3.2 & $1 \mathrm{~N} 12 \mathrm{~A}$ & 134 & PapE pilus subunit \\
\hline 11 & B.2.3.2 & 1PDKB & 149 & PapK pilus subunit \\
\hline 12 & B.2.3.2 & 1ZE3H1 & 118 & (H: 159 - 279) Mannose-specific adhesin FimH \\
\hline 13 & B.2.3.2 & 1TR7A1 & 158 & Mannose-specific adhesin FimH \\
\hline 14 & B.2.3.3 & 1J8RA & 196 & PapG adhesin receptor-binding domain \\
\hline 15 & B.2.3.5 & 109VA & 168 & Fimbrial adhesin F17-AG lectin domain \\
\hline 16 & B.2.3.6 & 1USZA & 140 & DraA/Afimbrial adhesin Afa-III \\
\hline 17 & B.6.1.2 & 1FFTB1 & 166 & (B: 118 - 283) Quinol oxidase (CyoA) \\
\hline 18 & B.6.1.3 & 1N68A1 & 141 & (A: 30 - 170) Multi-copper oxidase CueO \\
\hline 19 & B.6.1.3 & 1N68A2 & 165 & (A: 171 - 335) Multi-copper oxidase CueO \\
\hline 20 & B.6.1.3 & 1N68A3 & 158 & (A: 336 - 516) Multi-copper oxidase CueO \\
\hline 21 & B.17.1.2 & 1FJJA & 154 & Hypothetical protein YbhB \\
\hline 22 & B.18.1.5 & 1BGLA3 & 217 & beta-Galactosidase \\
\hline 23 & B.30.2.1 & 1D6UA1 & 424 & (A: 301 - 724) Copper amine oxidase, domain 3 \\
\hline 24 & B.30.5.11 & 2F2HA2 & 247 & Putative glucosidase YicI, N-terminal domain \\
\hline 25 & B.33.1.3 & 2JO6A1 & 108 & NADH-nitrite reductase small subunit \\
\hline 26 & B.34.5.1 & 1VS6U1 & 102 & Ribosomal proteins L24 (L24p) \\
\hline 27 & B.34.6.2 & 1UB4A & 103 & MazF protein \\
\hline 28 & B.35.1.2 & 1O89A1 & 143 & (A: 1 - 115, A: 293 - 323) Hypothetical protein YhdH \\
\hline 29 & B.35.1.2 & 1QORA1 & 147 & (A: 2 - 112, A: 292 - 327) Quinone oxidoreductase \\
\hline 30 & B.36.1.4 & 1TE0A1 & 100 & Stress sensor protease DegS, C-terminal domain \\
\hline 31 & B.40.2.1 & 1B44D & 106 & Heat-labile toxin type IB \\
\hline 32 & B.40.4.1 & 1E1OA1 & 143 & Lysyl-tRNA synthetase (LysRS) \\
\hline 33 & B.40.4.3 & 1V1QA & 110 & Primosomal replication protein N, PriB \\
\hline 34 & B.40.4.3 & 1QVCA & 145 & ssDNA-binding protein \\
\hline
\end{tabular}




\section{Continued}

\begin{tabular}{|c|c|c|c|c|}
\hline 35 & B.40.5.1 & 1FAJA & 168 & Inorganic pyrophosphatase \\
\hline 36 & B.40.6.3 & 2AWNA1 & 135 & Maltose transport protein MalK, C-terminal domain \\
\hline 37 & B.40.9.1 & 1SR3A & 114 & Heme chaperone CcmE \\
\hline 38 & B.43.2.1 & 1FUIA1 & 236 & (A: 356 - 591) L-fucose isomerase, C-terminal domain \\
\hline 39 & B.43.2.2 & 2AJTA1 & 170 & (A: 329 - 498) L-arabinose isomerase AraA \\
\hline 40 & B.43.4.1 & 1DDGA1 & 221 & (A: 226 - 446) Sulfite reductase flavoprotein \\
\hline 41 & B.43.4.2 & 1GVHA2 & 107 & (A: 147 - 253) Flavohemoglobin, central domain \\
\hline 42 & B.43.4.3 & 1I8DA2 & 113 & (A: 94 - 206) Riboflavin synthase \\
\hline 43 & B.45.1.3 & 2IDBA1 & 308 & 3-octaprenyl-4-hydroxybenzoate carboxy-lyase \\
\hline 44 & B.46.1.1 & 1FMTA1 & 108 & Methionyl-trnafmet formyltransferase \\
\hline 45 & B.49.2.3 & 1KNWA1 & 174 & (A:2-31,A:279-422) Diaminopimelate decarboxylase \\
\hline 46 & B.52.1.4 & 2AE0X1 & 335 & Membrane-bound lytic murein transglycosylase A \\
\hline 47 & B.52.2.1 & 1PPYA & 118 & Pyruvoyl dependent aspartate decarboxylase \\
\hline 48 & B.52.2.2 & 1AA6A1 & 132 & (A: 565 - 715) Formate dehydrogenase $\mathrm{H}$ \\
\hline 49 & B.52.2.2 & 1Q16A1 & 170 & Respiratory nitrate reductase 1 alpha chain \\
\hline 50 & B.53.1.2 & 1EUQA1 & 198 & (A: 339 - 547) Gln-tRNA synthetase, C-terminal \\
\hline 51 & B.58.1.2 & $1065 \mathrm{~A}$ & 218 & Hypothetical protein YiiM \\
\hline 52 & B.60.1.1 & 1QWDA & 167 & Outer membrane lipoprotein Blc \\
\hline 53 & B.60.1.4 & 1OEJA & 187 & Hypothetical protein YodA \\
\hline 54 & B.68.4.1 & 1C5KA1 & 269 & (A: 163 - 431) TolB, C-terminal domain \\
\hline 55 & B.69.11.1 & 1RI6A & 333 & Putative isomerase $\mathrm{YbhE}$ \\
\hline 56 & B.80.6.1 & 1VH4B & 410 & Stabilizer of iron transporter SufD \\
\hline 57 & B.81.1.1 & 1LXAA & 262 & UDP N-acetylglucosamine acyltransferase \\
\hline 58 & B.81.1.4 & 1HV9A1 & 200 & N-acetylglucosamine 1-phosphate uridyltransferase \\
\hline 59 & B.82.1.11 & 1RC6A & 242 & Hypothetical protein YlbA \\
\hline 60 & B.82.1.12 & 1TQ5A1 & 230 & Hypothetical protein YhhW \\
\hline 61 & B.82.1.13 & 1XRUA1 & 277 & 5-keto-4-deoxyuronate isomerase Kdul \\
\hline 62 & B.82.1.14 & 1YQCA1 & 159 & Ureidoglycolate hydrolase AIIA \\
\hline 63 & B.82.1.23 & 2D40A1 & 288 & (A: 35 - 342) Gentisate 1,2-dioxygenase \\
\hline 64 & B.82.2.3 & 1JR7A & 306 & Gab protein (hypothetical protein YgaT) \\
\hline 65 & B.82.2.5 & 1OTJA & 281 & Taurine/alpha-ketoglutarate dioxygenase TauD \\
\hline 66 & B.82.2.10 & 2FD8A1 & 199 & (A: 15 - 214) Alkylated DNA repair protein AlkB \\
\hline 67 & B.82.2.13 & 3BB6A1 & 104 & Uncharacterized protein YeaR \\
\hline 68 & B.82.3.2 & 1I5ZA2 & 132 & Catabolite gene activator protein \\
\hline 69 & B.82.4.1 & 1XJAC & 165 & Regulatory protein AraC \\
\hline 70 & B.84.2.1 & 1BNCA1 & 116 & (A: 331 - 446) Biotin carboxylase, C-domain \\
\hline
\end{tabular}




\section{Continued}

\begin{tabular}{|c|c|c|c|c|}
\hline 71 & B.84.3.1 & 2F3GA & 150 & Glucose-specific factor III (glsIII) \\
\hline 72 & B.85.4.1 & 1DUDA & 136 & Deoxyuridine 5'-triphosphate nucleotidohydrolase \\
\hline 73 & B.85.4.1 & $1 \mathrm{XS} 1 \mathrm{~A}$ & 193 & Deoxycytidine triphosphate deaminase \\
\hline 74 & B.87.1.1 & 1JHHB & 124 & LexA repressor C-terminal domain \\
\hline 75 & B.87.1.2 & $1 \mathrm{KN} 9 \mathrm{~A}$ & 234 & Type 1 signal peptidase \\
\hline 76 & B.92.1.2 & 1K6WA1 & 103 & (A: 4 - 55, A: 376 - 426) Cytosine deaminase \\
\hline 77 & B.92.1.7 & 1ONWA1 & 105 & (A: 1 - 62,A: 347 - 389) Isoaspartyl dipeptidase \\
\hline 78 & B.110.1.1 & 1RH1A1 & 290 & (A: 10 - 312) Colicin B N-terminal domain \\
\hline 79 & B.113.1.1 & 1K3WA2 & 124 & Endonuclease VIII \\
\hline 80 & B.122.1.7 & 1TE7A & 103 & Hypothetical protein YqfB \\
\hline 81 & B.122.1.10 & 2ANEA1 & 110 & ATP-dependent protease La, N-terminal domain \\
\hline 82 & B.125.1.1 & 1IWLA & 177 & Outer-membrane lipoproteins carrier protein LolA \\
\hline 83 & B.125.1.2 & 1IWMA & 177 & Outer membrane lipoprotein receptor LolB \\
\hline 84 & B.130.1.1 & 1BPRA1 & 126 & (A: 381 - 506) Chaperone DnaK \\
\hline 85 & B.136.1.1 & 10X9A & 108 & Stringent starvation protein B, SspB \\
\hline 86 & B.142.1.1 & 1NA6A1 & 172 & Restriction endonuclease EecoRII, N-terminal domain \\
\hline 87 & B.150.1.1 & 1XSIA1 & 108 & Putative glucosidase YicI, C-terminal domain \\
\hline 88 & B.153.1.2 & 1NI5A3 & 118 & (A: 315 - 432) tRNA-Ile-lysidine synthetase, TilS \\
\hline 89 & B.167.1.1 & 1ZE3D1 & 116 & Outer membrane usher protein FimD \\
\hline 90 & B.177.1.1 & 2IN5A1 & 195 & Hypothetical lipoprotein YmcC \\
\hline \multicolumn{5}{|c|}{ T. maritima } \\
\hline 1 & B.1.9.2 & $1 \mathrm{I} 82 \mathrm{~A}$ & 189 & Xylanase 10A \\
\hline 2 & B.3.1.3 & 2J71A1 & 102 & Pullulanase PulA \\
\hline 3 & B.18.1.14 & 1GUIA & 155 & Carbohydrate binding module from laminarinase $16 \mathrm{~A}$ \\
\hline 4 & B.23.3.1 & 2F4LA1 & 274 & Putative acetamidase TM0119 \\
\hline 5 & B.29.1.19 & 1UYPA1 & 138 & Beta-fructosidase (invertase), C-terminal domain \\
\hline 6 & B.30.5.11 & 1ZY9A1 & 171 & Alpha-galactosidase GalA N-terminal domain \\
\hline 7 & B.35.1.2 & 1VJ0A1 & 154 & Hypothetical protein TM0436 \\
\hline 8 & B.40.4.9 & 1GM5A2 & 175 & (A: 106 - 285) RecG “wedge” domain \\
\hline 9 & B.40.7.1 & $1 \mathrm{~K} 0 \mathrm{SA}$ & 151 & Chemotaxis protein CheW \\
\hline 10 & B.40.11.1 & 2F4IA1 & 172 & (A: 39 - 214) Hypothetical protein TM0957 \\
\hline 11 & B.47.1.1 & 1L1JA & 226 & Protease Do (DegP, HtrA), catalytic domain \\
\hline 12 & B.62.1.3 & 1ZX8A1 & 123 & Hypothetical protein TM1367 \\
\hline 13 & B.67.2.4 & 1VKDA & 324 & Hypothetical protein TM1225 \\
\hline 14 & B.80.3.1 & 1HF2A1 & 107 & Cell-division inhibitor MinC, C-terminal domain \\
\hline 15 & B.82.1.9 & 2F4PA1 & 134 & Hypothetical protein TM1010 \\
\hline
\end{tabular}




\section{Continued}

\begin{tabular}{|c|c|c|c|c|}
\hline 16 & B.82.1.9 & 1O4TA & 115 & Hypothetical protein TM1287 \\
\hline 17 & B.123.1.1 & 1NC7A & 114 & Hypothetical protein TM1070 \\
\hline \multicolumn{5}{|c|}{ T. thermophilus } \\
\hline 1 & B.1.18.19 & 1V8HA1 & 106 & Sulfur oxidation protein SoxZ \\
\hline 2 & B.6.1.2 & 2CUAB & 122 & Cytochrome c oxidase \\
\hline 3 & B.33.1.1 & 1NYKA & 156 & Soluble Rieske protein \\
\hline 4 & B.34.5.1 & 1VSAS1 & 101 & Ribosomal proteins L24 \\
\hline 5 & B.34.5.3 & 2HGJD1 & 147 & Ribosomal protein L2, C-terminal domain \\
\hline 6 & B.34.5.6 & 2J01T1 & 137 & Ribosomal protein L19 \\
\hline 7 & B.39.1.1 & 1VSAI1 & 122 & Ribosomal protein L14 \\
\hline 8 & B.40.4.1 & 1EFWA1 & 104 & Aspartyl-tRNA synthetase \\
\hline 9 & B.40.4.4 & 1GD7A & 109 & TRBP111 homolog CsaA \\
\hline 10 & B.40.4.4 & 1B70B3 & 113 & (B: 39 - 151) Domain B2 of PheRS-beta, PheT \\
\hline 11 & B.40.4.5 & 1FJGQ & 104 & Ribosomal protein S17 \\
\hline 12 & B.40.4.5 & 2J03D2 & 125 & Ribosomal protein L2, N-terminal domain \\
\hline 13 & B.40.4.5 & 1I94L & 131 & Ribosomal protein S12 \\
\hline 14 & B.43.3.1 & 1WDTA1 & 103 & (A: 275 - 377) Elongation factor G, domain II \\
\hline 15 & B.43.3.1 & 1AIPA1 & 100 & Elongation factor Tu, domain 2 \\
\hline 16 & B.43.3.2 & 2HGJE1 & 205 & Ribosomal protein L3 \\
\hline 17 & B.45.1.2 & 1USCA & 178 & Putative styrene monooxygenase small component \\
\hline 18 & B.51.1.1 & 1ILEA2 & 189 & (A: 198 - 386) Isoleucyl-tRNA synthetase \\
\hline 19 & B.53.1.1 & 1FEUD & 185 & Ribosomal protein TL5 (general stress protein CTC) \\
\hline 20 & B.61.6.1 & 1WUBA & 176 & Polyisoprenoid-binding protein TTHA0802 \\
\hline 21 & В.82.1.9 & $1 \mathrm{~V} 70 \mathrm{~A}$ & 105 & Hypothetical protein TTHA0104 \\
\hline 22 & B.84.1.1 & 1ONLA & 127 & Protein $\mathrm{H}$ of glycine cleavage system \\
\hline 23 & B.111.1.1 & $1 \mathrm{~J} 1 \mathrm{HA}$ & 123 & Small protein B \\
\hline 24 & B.113.1.1 & 1EE8A2 & 121 & DNA repair protein MutM (Fpg) \\
\hline 25 & B.117.1.1 & 1UDXA1 & 156 & Obg GTP-binding protein N-terminal domain \\
\hline 26 & B.122.1.3 & 1V47A1 & 132 & ATP sulfurylase N-terminal domain \\
\hline 27 & B.153.1.1 & 1B70B6 & 209 & (B: 191 - 399) B3/B4 domain of PheRS, PheT \\
\hline 28 & B.155.1.1 & 1VSAP1 & 101 & Ribosomal protein L21p \\
\hline \multicolumn{5}{|c|}{ human } \\
\hline 1 & B.1.1.1 & 1CDBA & 105 & CD2, first domain \\
\hline 2 & B.1.1.1 & 1AKJD & 114 & CD8 \\
\hline 3 & B.1.1.1 & 1G9MH1 & 129 & Immunoglobulin heavy chain variable domain \\
\hline 4 & B.1.1.1 & $1 \mathrm{I} 85 \mathrm{C}$ & 118 & Immunoreceptor CTLA-4, N-terminal fragment \\
\hline
\end{tabular}




\section{Continued}

\begin{tabular}{|c|c|c|c|c|}
\hline 5 & B.1.1.1 & $1 \mathrm{KACB}$ & 124 & Coxsackie virus and adenovirus receptor \\
\hline 6 & B.1.1.1 & 1O7SA & 112 & Sialic acid binding Ig-like lectin 7 \\
\hline 7 & B.1.1.1 & 1TVDA & 116 & T-cell antigen receptor \\
\hline 8 & B.1.1.2 & 1А9BB & 100 & beta2-microglobulin \\
\hline 9 & B.1.1.2 & 1BD2E2 & 129 & (E: 119 - 247) T-cell antigen receptor \\
\hline 10 & B.1.1.3 & 1IJ9A1 & 106 & (A: 91 - 196) Vascular cell adhesion molecule-1 \\
\hline 11 & B.1.1.3 & 1ZXQA1 & 106 & (A: 87 - 192) Intercellular cell adhesion molecule-2 \\
\hline 12 & B.1.1.4 & 2AVGA1 & 110 & Cardiac myosin binding protein c, different domains \\
\hline 13 & B.1.1.4 & 2CQVA1 & 101 & Telokin \\
\hline 14 & B.1.1.4 & 1BQSA2 & 119 & Mucosal addressin cell adhesion molecule-1 \\
\hline 15 & B.1.1.4 & 1CVSC2 & 109 & (C: 251 - 359) Fibroblast growth factor receptor \\
\hline 16 & B.1.1.4 & 1EFXD1 & 100 & (D: 4 - 103) Killer cell inhibitory receptor \\
\hline 17 & B.1.1.4 & 1II4F1 & 101 & (F: 150 - 250) Fibroblast growth factor receptor \\
\hline 18 & B.1.1.4 & 1NBQA2 & 104 & Junction adhesion molecule, C-terminal domain \\
\hline 19 & B.1.1.4 & 1QSVA & 101 & Fflt-1 receptor second domain \\
\hline 20 & B.1.1.4 & 1WWAX & 105 & High affinity nerve growth factor receptor \\
\hline 21 & B.1.1.4 & 3В5HA1 & 101 & (A: 103 - 203) Cervical EMMPRIN \\
\hline 22 & B.1.2.1 & 1WF5A1 & 108 & (A: 8 - 115) Sidekick 2 \\
\hline 23 & B.1.2.1 & 1AXIB2 & 106 & (B: 131 - 236) Growth hormone receptor \\
\hline 24 & B.1.2.1 & $1 \mathrm{WK} 0 \mathrm{~A}$ & 137 & Fibronectin type-III domain containing protein 3a \\
\hline 25 & B.1.2.1 & 1X5KA1 & 111 & (A: 8 - 118) Neogenin \\
\hline 26 & B.1.2.1 & 2CSPA1 & 117 & Rim binding protein 2 \\
\hline 27 & B.1.2.1 & 2CUHA1 & 102 & Tenascin-x \\
\hline 28 & B.1.2.1 & 2HAZA1 & 101 & (A: 489 - 589) Neural cell adhesion molecule 1 \\
\hline 29 & B.1.2.1 & 1EBAA2 & 105 & (A: 117 - 224) erythropoietin receptor \\
\hline 30 & B.1.2.1 & 1F42A2 & 119 & (A: 88 - 211) The p40 domain of interleukin-12 \\
\hline 31 & B.1.2.1 & 1FG9C2 & 112 & Interferon-gamma receptor alpha chain \\
\hline 32 & B.1.2.1 & 1GH7A1 & 103 & GM-CSF, IL-3 and IL-5 receptor beta-chain \\
\hline 33 & B.1.2.1 & 1I1RA1 & 100 & Cytokine receptor gp130 cytokine-binding domains \\
\hline 34 & B.1.2.1 & 1J7VR2 & 106 & (R: 101 - 206) Interleukin-10 receptor 1 \\
\hline 35 & B.1.2.1 & 1N26A2 & 102 & (A: 94 - 195) Interleukin-6 receptor alpha chain \\
\hline 36 & B.1.2.1 & 1N6UA2 & 103 & Interferon-alpha/beta receptor beta chain \\
\hline 37 & B.1.2.1 & 2D9QB3 & 107 & (B: 97 - 203) Granulocyte colony-stimulating factor \\
\hline 38 & B.1.2.1 & 1EBAA1 & 107 & (A: 10 - 116) Erythropoietin receptor \\
\hline 39 & B.1.2.1 & 1GH7A2 & 114 & GM-CSF, IL-3 and IL-5 receptor beta chain \\
\hline 40 & B.1.2.1 & 1N6UA1 & 109 & Interferon-alpha/beta receptor beta chain \\
\hline
\end{tabular}




\section{Continued}

\begin{tabular}{|c|c|c|c|c|}
\hline 41 & B.1.3.1 & 1WGOA & 123 & VPS10 domain-containing receptor SorCS2 \\
\hline 42 & B.1.4.1 & 1BHGA1 & 103 & (A: 226 - 328) beta-Glucuronidase \\
\hline 43 & B.1.5.1 & 1EVUA2 & 112 & Transglutaminase, two C-terminal domains \\
\hline 44 & B.1.5.1 & 2Q3ZA2 & 114 & Transglutaminase, two C-terminal domains \\
\hline 45 & B.1.5.1 & 1EVUA3 & 100 & Transglutaminase, two C-terminal domains \\
\hline 46 & B.1.10.1 & 1E42A1 & 120 & Beta2-adaptin AP2 ear domain, N-terminal subdomain \\
\hline 47 & B.1.10.2 & 2DWXA1 & 129 & ADP-ribosylation factor binding protein Gga1 domain \\
\hline 48 & B.1.10.3 & 1R4XA1 & 163 & Coatomer gamma subunit C-terminal domain \\
\hline 49 & B.1.16.1 & 1IVTA & 122 & Lamin A/C globular tail domain \\
\hline 50 & B.1.18.1 & 1OWRM1 & 103 & (M: 576 - 678) T-cell transcription factor NFAT1 \\
\hline 51 & B.1.18.9 & 1L9MA1 & 140 & Transglutaminase N-terminal domain \\
\hline 52 & B.1.18.10 & 2DIBA1 & 115 & Filamin b \\
\hline 53 & B.1.18.10 & 2DMCA1 & 103 & Filamin b \\
\hline 54 & B.1.18.23 & 3ES6B1 & 118 & Prolactin-inducible protein \\
\hline 55 & B.2.5.2 & 1TSRB & 194 & p53 tumor suppressor, DNA-binding domain \\
\hline 56 & B.2.5.3 & 1A02N2 & 178 & T-cell transcription factor, DNA-binding domain \\
\hline 57 & B.2.5.3 & 1SVCP2 & 208 & (P: 43 - 250) p50 subunit of NF-kappa B \\
\hline 58 & B.2.5.4 & 1H6FA & 184 & T-box protein 3 \\
\hline 59 & B.2.5.5 & 1BF5A2 & 252 & (A: 317 - 568) STAT-1, DNA-binding domain \\
\hline 60 & B.2.5.6 & $1 \mathrm{E} 50 \mathrm{C}$ & 125 & Acute myeloid leukemia 1 protein \\
\hline 61 & B.2.7.1 & 1H6EA & 219 & Mu2 adaptin subunit of ap2 adaptor second domain \\
\hline 62 & B.2.9.1 & 1WD8A1 & 155 & (A: 113 - 293) Ppeptidylarginine deiminase \\
\hline 63 & B.3.3.1 & 1LM8V & 150 & VHL \\
\hline 64 & B.3.4.1 & 1BM7A & 114 & Transthyretin (Prealbumin) \\
\hline 65 & B.6.1.3 & 1KCWA1 & 192 & Ceruloplasmin \\
\hline 66 & B.7.1.1 & 1BCIA & 123 & Domain from cytosolic phospholipase A2 \\
\hline 67 & B.7.1.1 & 2EP6A1 & 126 & Multiple C2 and transmembrane domain-containg protein \\
\hline 68 & B.7.1.1 & 2FJUB2 & 122 & (B: 678 - 799) Phospholipase C-beta-2 \\
\hline 69 & B.7.1.1 & 2YRBA1 & 142 & (A: 596 - 737) Fantom \\
\hline 70 & B.7.1.1 & 1D5RA1 & 125 & Pten tumor suppressor (Phoshphoinositide phosphatase) \\
\hline 71 & B.7.1.1 & 1E8YA2 & 135 & (A: 357 - 522) Phoshoinositide 3-kinase \\
\hline 72 & B.7.1.1 & 2NQ3A1 & 131 & E3 ubiquitin-protein ligase \\
\hline 73 & B.7.1.2 & 2R83A1 & 123 & (A: 271 - 393) Synaptogamin I \\
\hline 74 & B.7.1.2 & 1WFMA & 138 & Synaptotagmin XIII \\
\hline 75 & B.8.1.1 & 1FLKA1 & 155 & (A: 350 - 504) TNF receptor associated factor 3 \\
\hline 76 & B.8.1.1 & 2CR2A1 & 146 & Speckle-type poz protein \\
\hline
\end{tabular}




\section{Continued}

\begin{tabular}{|c|c|c|c|c|}
\hline 77 & B.14.1.1 & 1KFUL2 & 159 & (L: 356 - 514) Calpain large subunit, middle domain \\
\hline 78 & B.15.1.2 & 1EJFA & 110 & Co-chaperone p23 \\
\hline 79 & B.15.1.3 & 1WH0A & 134 & Ubiquitin carboxyl-terminal hydrolase 19 \\
\hline 80 & B.15.1.4 & 1WGVA & 124 & NudC domain containing protein 3 \\
\hline 81 & B.18.1.4 & 2BBAA1 & 180 & (A: 17 - 196) Ephrin type-b receptor 4 \\
\hline 82 & B.18.1.8 & 1XNAA & 151 & $\mathrm{~N}$-terminal domain of xrcc1 \\
\hline 83 & B.18.1.9 & 1XPWA & 143 & Placental protein 25 \\
\hline 84 & B.22.1.1 & 1RJ7A & 144 & Ectodysplasin A \\
\hline 85 & B.22.1.1 & 1PK6C & 129 & Complement c1q globular head, $\mathrm{C}$ chain \\
\hline 86 & B.22.1.1 & 1TNRA & 144 & Tumor necrosis factor \\
\hline 87 & B.22.1.1 & 1ALYA & 146 & Extracellular domain of CD40 ligand \\
\hline 88 & B.23.1.1 & 1SZBA1 & 121 & Mannose-binding protein associated serine protease 2 \\
\hline 89 & B.26.1.1 & 1DD1A & 221 & Smad4 tumor suppressor C-terminal domain \\
\hline 90 & B.26.1.2 & $1 \mathrm{R} 21 \mathrm{~A}$ & 100 & Antigen Ki-67 \\
\hline 91 & B.26.1.2 & 2BRFA1 & 100 & (A: 8 - 108) Polynucleotide kinase 3'-phosphatase \\
\hline 92 & B.26.1.2 & 2G1LA1 & 102 & (A: 498 - 599) Kinesin-like protein kif1c \\
\hline 93 & B.26.1.2 & 2PIEA1 & 127 & (A: 13 - 139) Ubiquitin ligase protein RNF8 \\
\hline 94 & B.26.1.2 & 1GXCA & 116 & Chk2 kinase \\
\hline 95 & B.29.1.3 & 1АЗКА & 137 & Galectin-3 CRD \\
\hline 96 & B.29.1.4 & 1H30A2 & 205 & (A: 461 - 678) growth-arrest-specific protein Gas6 \\
\hline 97 & B.29.1.5 & 1B09A & 206 & C-reactive protein \\
\hline 98 & B.29.1.22 & 2FBEA1 & 188 & Similar to Ret finger protein-like 1 \\
\hline 99 & B.34.2.1 & 1NG2A2 & 118 & p47pox (neutrophil cytosolic factor 1 ) \\
\hline 100 & B.34.9.2 & 1RI0A & 100 & Hepatoma-derived growth factor \\
\hline 101 & B.34.9.3 & 1WJRA & 127 & Scm-like with four MBT domains protein 2 \\
\hline 102 & B.34.10.1 & 2CP6A1 & 160 & (A: 8 - 167) Restin \\
\hline 103 & B.34.10.1 & 1IXDA & 104 & Cylindromatosis tumour-suppressor \\
\hline 104 & B.34.14.1 & $1 \mathrm{SI} 2 \mathrm{~A}$ & 120 & Eukaryotic translation initiation factor 2C 1 \\
\hline 105 & B.36.1.1 & 1UEQA & 123 & Membrane associated guanylate kinase inverted-2 \\
\hline 106 & B.36.1.1 & 1UF1A & 128 & KIAA1526 protein \\
\hline 107 & B.36.1.2 & $1 \mathrm{I} 16 \mathrm{~A}$ & 130 & Interleukin 16 \\
\hline 108 & B.40.3.3 & 1UAPA & 131 & Procollagen c-proteinase enhancer protein \\
\hline 109 & B.40.4.3 & 1EWIA & 114 & Replication protein A 70 KDa subunit \\
\hline 110 & B.40.4.3 & 1FGUA1 & 118 & (A: 181 - 298) Replication protein A 70 KDa subunit \\
\hline 111 & B.40.4.3 & 1XJVA2 & 151 & (A: 149 - 299) Protection of telomeres protein 1 \\
\hline 112 & B.40.4.3 & 2PQAB1 & 114 & (B: 3 - 116) Rreplication protein A 14 KDa \\
\hline
\end{tabular}




\section{Continued}

\begin{tabular}{|c|c|c|c|c|}
\hline 113 & B.40.4.3 & 1FGUA2 & 128 & (A: 299 - 426) Replication protein A 70 KDa subunit \\
\hline 114 & B.40.4.3 & 2PI2A1 & 121 & (A: 44 - 171) Replication protein A $32 \mathrm{KDa}$ subunit \\
\hline 115 & B.40.4.3 & 1XJVA1 & 140 & (A: 6 - 145) protection of telomeres protein 1 \\
\hline 116 & B.40.4.4 & 1NTGA & 171 & Metazoan tyrosyl-tRNA synthetase, C-terminal domain \\
\hline 117 & B.40.4.5 & 1WI5A & 119 & RRP5 protein homolog S1-domain \\
\hline 118 & B.40.4.5 & 2NN6I1 & 125 & (I: 61 - 185) Exosome component 1 \\
\hline 119 & B.40.4.5 & 1D7QA & 143 & Translation initiation factor-1a \\
\hline 120 & B.40.4.6 & 1X9NA2 & 148 & (A: 754 - 901) DNA ligase I \\
\hline 121 & B.40.16.1 & 2OQ0A2 & 101 & (A: 12 - 114) Gamma-interferon-inducible protein \\
\hline 122 & B.42.1.1 & 1AXMC & 128 & Acidic FGF \\
\hline 123 & B.42.1.2 & 1IOBA & 153 & Interleukin-1 beta \\
\hline 124 & B.42.1.2 & 1J0SA & 157 & Interleukin-18 \\
\hline 125 & B.42.5.1 & 1DFCB3 & 120 & (B: 2260 - 2382) Fascin \\
\hline 126 & B.43.4.2 & 1UMKA1 & 124 & (A: 30 - 153) Cytochrome b5 reductase \\
\hline 127 & B.43.5.1 & 1NB0A & 147 & Riboflavin kinase \\
\hline 128 & B.45.1.1 & 1XHNA1 & 170 & Cellular repressor of E1A-stimulated genes \\
\hline 129 & B.46.1.1 & 2BW0A1 & 104 & 10-formyltetrahydrofolate dehydrogenase domain 2 \\
\hline 130 & B.46.1.2 & 1F6OA & 211 & 3-methyladenine DNA glycosylase \\
\hline 131 & B.47.1.2 & 1TRNA & 224 & Trypsin(ogen) \\
\hline 132 & B.54.1.1 & 1CL3A & 138 & Core binding factor beta \\
\hline 133 & B.55.1.1 & 1BAKA & 119 & G-protein coupled receptor kinase 2 \\
\hline 134 & B.55.1.1 & 1DYNA & 113 & Dynamin \\
\hline 135 & B.55.1.1 & $1 \mathrm{~V} 88 \mathrm{~A}$ & 130 & Oxysterol binding protein-related protein 8 \\
\hline 136 & B.55.1.1 & 1X1FA1 & 136 & (A: 8 - 143) Signal-transducing adaptor protein 1 \\
\hline 137 & B.55.1.1 & 1X1GA1 & 116 & (A: 8 - 123) Pleckstrin-2 \\
\hline 138 & B.55.1.1 & 1XD4A3 & 131 & (A: 419 - 549) Son of sevenless-1 \\
\hline 139 & B.55.1.1 & 2COAA1 & 112 & Protein kinase c, d2 type \\
\hline 140 & B.55.1.1 & 1B55A & 163 & Bruton’s tyrosine kinase \\
\hline 141 & B.55.1.1 & 1KI1B2 & 132 & (B: 1439 - 1580) GEF of intersectin \\
\hline 142 & B.55.1.1 & 1UNPA & 119 & Rac-alpha serine/threonine kinase \\
\hline 143 & B.55.1.1 & 2FJUB3 & 131 & Phospholipase c-beta-2 \\
\hline 144 & B.55.1.2 & 1OY2A & 191 & Shc adaptor protein \\
\hline 145 & B.55.1.2 & 2DKQA1 & 147 & Tensin \\
\hline 146 & B.55.1.2 & 1XR0B & 126 & FGFR substrate 2 \\
\hline 147 & B.55.1.2 & 1J0WB & 103 & Downstream of tyrosine kinase 5 \\
\hline 148 & B.55.1.3 & $1 \mathrm{~K} 5 \mathrm{DB}$ & 146 & Ran-binding protein 1 \\
\hline
\end{tabular}




\section{Continued}

\begin{tabular}{|c|c|c|c|c|}
\hline 149 & B.55.1.4 & 2IYBA1 & 111 & Enabled \\
\hline 150 & B.55.1.5 & 1E5WA2 & 148 & (A: 199 - 346) Moesin \\
\hline 151 & B.55.1.6 & 1MIA2 & 109 & (A: 2140 - 2248) PH-like domain of neurobeachin \\
\hline 152 & B.55.1.8 & 1LW3A1 & 125 & Myotubularin-related protein 2, N-terminal domain \\
\hline 153 & B.55.1.9 & 1PFJA & 108 & TFIIH basal transcription factor complex 62 subunit \\
\hline 154 & B.55.1.12 & 2HTHB1 & 129 & Vacuolar protein sorting protein 36 \\
\hline 155 & B.59.1.1 & 1FU1A1 & 117 & XRCC4, N-terminal domain \\
\hline 156 & B.60.1.1 & $1 \mathrm{XKIA}$ & 128 & Von Ebner's gland protein \\
\hline 157 & B.60.1.1 & 1IW2A & 163 & Complement protein C8 gamma \\
\hline 158 & B.60.1.2 & 1B56A & 133 & Epidermal fatty acid binding protein \\
\hline 159 & B.61.5.1 & $1 \mathrm{~K} 3 \mathrm{BA}$ & 119 & Dipeptidyl peptidase I (cathepsin C) \\
\hline 160 & B.63.1.1 & 1QTTA & 117 & p13-MTCP1 \\
\hline 161 & B.65.1.1 & 1F3UA & 118 & TFIIF beta subunit, Rap30 \\
\hline 162 & B.66.1.1 & 1SU3A2 & 195 & (A: 271 - 465) Collagenase, C-terminal domain \\
\hline 163 & B.67.3.1 & 1S18A & 317 & soluble calcium-activated nucleotidase SCAN-1 \\
\hline 164 & B.68.1.1 & 1SNTA & 352 & Sialidase 2 \\
\hline 165 & B.68.5.1 & 1IJQA1 & 258 & (A: 377 - 642) Low density lipoprotein receptor \\
\hline 166 & B.68.11.1 & 1U6DX & 288 & Kelch-like ECH-associated protein 1 \\
\hline 167 & B.69.5.1 & $1 \mathrm{I} 2 \mathrm{MB}$ & 388 & Regulator of chromosome condensation RCC1 \\
\hline 168 & B.69.8.1 & 1JV2A4 & 438 & Integrin alpha N-terminal domain \\
\hline 169 & B.69.12.1 & 1SHYB1 & 450 & (B: 40 - 515) Hepatocyte growth factor receptor \\
\hline 170 & B.69.14.1 & $1 \mathrm{XKSA}$ & 374 & Nuclear pore complex protein Nup133 \\
\hline 171 & B.70.3.1 & 1N1MA1 & 470 & Dipeptidyl peptidase IV/CD26, N-terminal domain \\
\hline 172 & B.74.1.1 & 1HUGA & 256 & Carbonic anhydrase \\
\hline 173 & B.76.2.1 & 1H3IA1 & 142 & Histone H3 K4-specific methyltransferase \\
\hline 174 & B.82.1.4 & $1 \mathrm{EY} 2 \mathrm{~A}$ & 419 & Homogentisate dioxygenase \\
\hline 175 & B.82.1.19 & 2IC1A1 & 185 & Cysteine dioxygenase type I \\
\hline 176 & B.82.2.6 & 1H2KA & 332 & Hypoxia-inducible factor ihhibitor \\
\hline 177 & B.82.2.10 & 2IUWA1 & 202 & (A: 70 - 279) AlkB homolog 3 \\
\hline 178 & B.85.7.1 & 2F69A2 & 166 & Histone H3 K4-specific methyltransferase \\
\hline 179 & B.88.1.1 & 1FWQA & 115 & RabGEF Mss4 \\
\hline 180 & B.88.1.2 & 1YZ1A1 & 144 & Translationally controlled tumor prtein \\
\hline 181 & B.95.1.1 & 2AF9A1 & 163 & Ganglioside M2 activator \\
\hline 182 & B.98.1.1 & 1GW6A2 & 208 & Leukotriene A4 hydrolase N-terminal domain \\
\hline 183 & B.122.1.12 & 3BI7A1 & 192 & (A: 414 - 617) E3 ubiquitin-protein ligase \\
\hline
\end{tabular}




\section{Continued}

\begin{tabular}{|c|c|c|c|c|}
\hline 184 & B.131.1.1 & 1JEQA3 & 285 & (A: 254 - 538) Ku70 subunit middle domain \\
\hline 185 & B.131.1.2 & 1JEQB1 & 298 & (B: 242 - 542) Ku80 subunit middle domain \\
\hline 186 & B.131.1.3 & $10 \mathrm{~W} 1 \mathrm{~A}$ & 167 & SMART/HDAC1 associated repressor protein \\
\hline 187 & B.145.1.1 & 1OA8A & 128 & Ataxin-1 \\
\hline \multicolumn{5}{|l|}{ yeast } \\
\hline 1 & B.1.8.1 & 1B4LA & 153 & $\mathrm{Cu}, \mathrm{Zn}$ superoxide dismutase \\
\hline 2 & B.1.8.1 & 1QUPB1 & 149 & Copper chaperone for superoxide dismutase \\
\hline 3 & B.1.22.1 & 2HUEA1 & 163 & Anti-silencing protein 1 \\
\hline 4 & B.2.8.1 & 1M2OA2 & 158 & (A: 2 - 44, A: 391 - 523) Sec23 \\
\hline 5 & B.2.8.1 & 1M2VB2 & 177 & (B: 61 - 215, B: 553 - 646) Sec24 \\
\hline 6 & B.17.1.1 & 1WPXB1 & 204 & (B: 501 - 719) Carboxypeptidase Y inhibitor \\
\hline 7 & B.18.1.9 & 1GQPA & 180 & Anaphase-promoting complex APC10/DOC1 subunit \\
\hline 8 & B.18.1.20 & 1R64A1 & 141 & (A: 461 - 601) Kexin, C-terminal domain \\
\hline 9 & B.18.1.22 & 1O59A1 & 177 & (A: 0 - 187) Allantoicase \\
\hline 10 & B.26.1.2 & 1G3GA & 164 & Phosphotyrosine binding domain of Rad53 \\
\hline 11 & B.26.1.2 & 1QU5A & 182 & Phosphotyrosine binding domain of Rad53 \\
\hline 12 & B.29.1.13 & 2A6VA1 & 218 & Emp46p N-terminal domain \\
\hline 13 & B.30.5.4 & 1Z45A1 & 342 & (A: 358 - 699) Galactose mutarotase \\
\hline 14 & B.38.4.1 & 2VGMA1 & 117 & Dom34 \\
\hline 15 & B.40.4.3 & 1KXLA & 187 & CDC13 ssDNA-binding domain \\
\hline 16 & B.40.4.5 & 2VNUD3 & 103 & (D: 252 - 399) Exosome complex exonuclease RRP44 \\
\hline 17 & B.40.4.16 & 2VNUD4 & 412 & (D: 495 - 910) Exosome complex exonuclease RRP44 \\
\hline 18 & B.40.5.1 & 1E6AA & 284 & Inorganic pyrophosphatase \\
\hline 19 & B.43.3.1 & 1N0UA1 & 138 & (A: 344 - 481) Elongation factor 2, domain II \\
\hline 20 & B.44.1.1 & 1G7CA2 & 109 & Elongation factor eEF-1alpha, C-terminal domain \\
\hline 21 & B.45.1.1 & $1 \mathrm{CI} 0 \mathrm{~A}$ & 205 & Pyridoxine 5'-phoshate oxidase \\
\hline 22 & B.50.1.2 & 1DP5A & 329 & Acid protease \\
\hline 23 & B.55.1.7 & 1Q67B & 146 & Dcp1 \\
\hline 24 & B.55.1.9 & 1Y5OA1 & 114 & RNA polymerase II transcription factor B 73KDa \\
\hline 25 & B.55.1.10 & 2GCLA1 & 230 & FACT complex subunit $\mathrm{POB}_{3}$, middle domain \\
\hline 26 & B.62.1.1 & 1ISTA & 161 & Cyclophilin (eukaryotic) \\
\hline 27 & B.69.4.1 & 1SQ9A & 378 & Antiviral protein Ski8 (Ski8p) \\
\hline 28 & B.69.4.1 & 1PGUA1 & 325 & Actin interacting protein 1 \\
\hline 29 & B.69.4.1 & 1NEXB2 & 344 & (B: 370 - 744) Cdc4 propeller domain \\
\hline 30 & B.69.4.2 & 1YFQA & 342 & Cell cycle arrest protein BUB3 \\
\hline
\end{tabular}


H. Nakashima et al.

\section{Continued}

\begin{tabular}{lllll}
\hline 31 & B.69.14.1 & 1XIPA & 367 & Nucleoporin NUP159 \\
32 & B.80.5.1 & 1K4ZA & 157 & Adenylylcyclase associated protein, C-terminal domain \\
33 & B.82.1.16 & 1XE7A & 186 & Hypothetical protein YML079W \\
34 & B.82.1.20 & 1ZVFA1 & 175 & 3-hydroxyanthranilate-3,4-dioxygenase \\
35 & B.86.1.2 & 1GPPA & 217 & VMA1-derived endonuclease PI-Scei intein \\
\hline
\end{tabular}


Scientific Research Publishing (SCIRP) is one of the largest Open Access journal publishers. It is currently publishing more than 200 open access, online, peer-reviewed journals covering a wide range of academic disciplines. SCIRP serves the worldwide academic communities and contributes to the progress and application of science with its publication.

Other selected journals from SCIRP are listed as below. Submit your manuscript to us via either submit@scirp.org or Online Submission Portal.
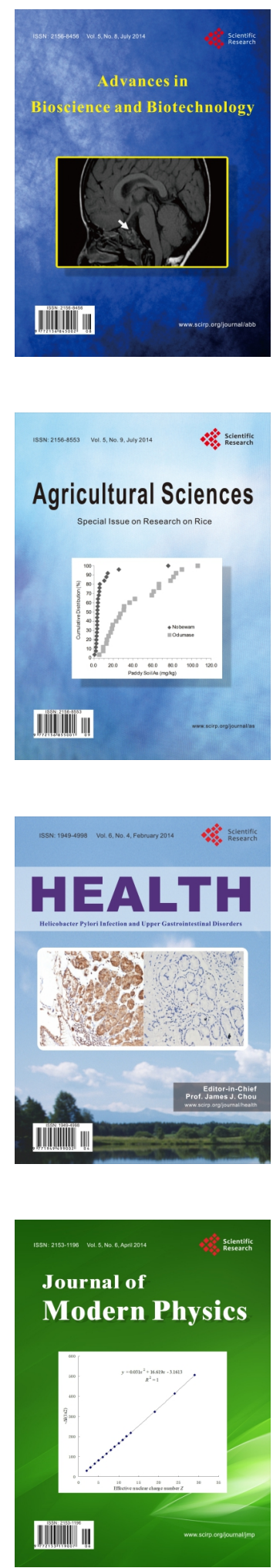
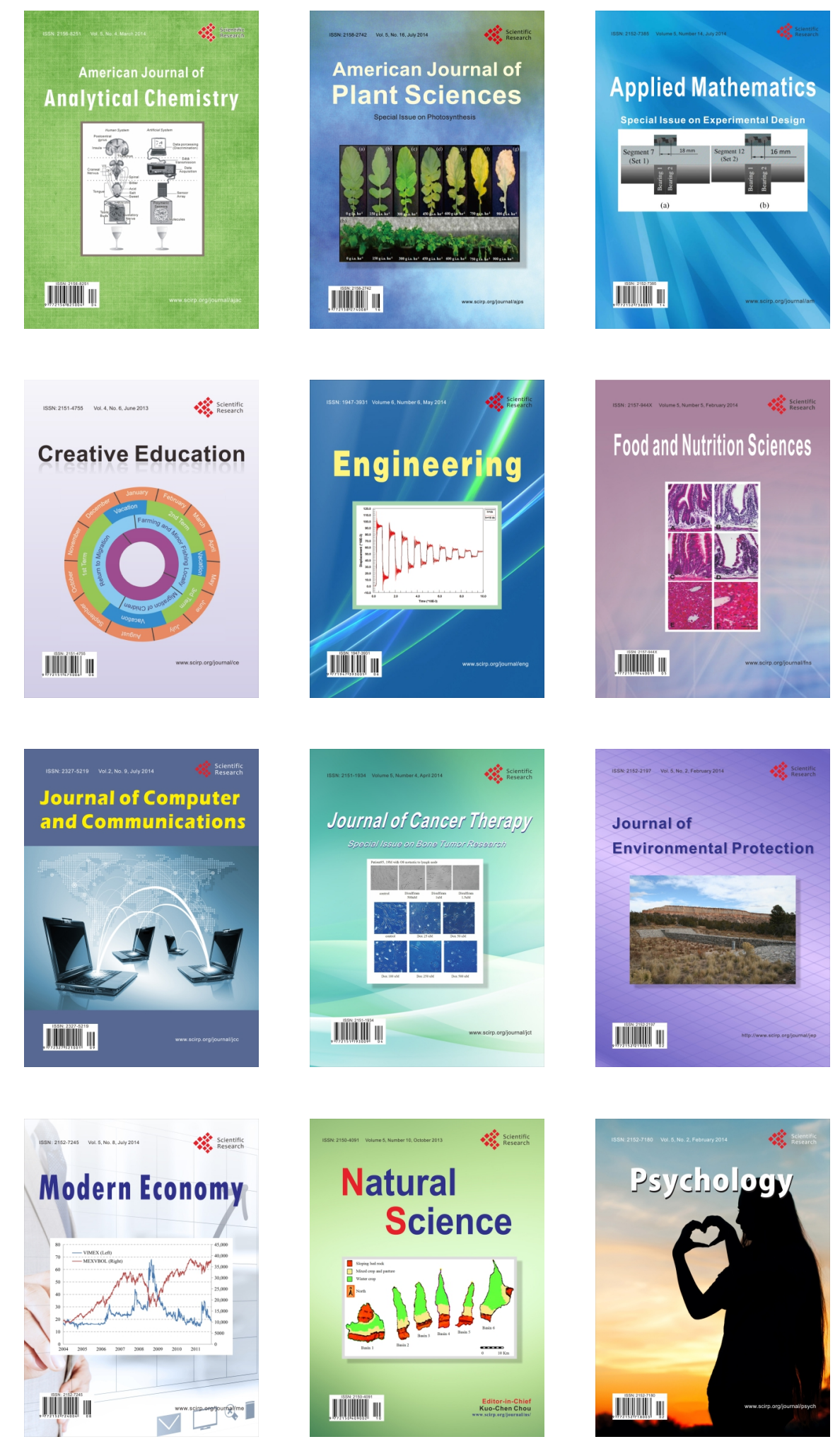